\title{
Episodic speleothem deposition tracks the terrestrial impact of millennial-scale last glacial climate variability in SW Ireland
}

\author{
Article
}

Accepted Version

Creative Commons: Attribution-Noncommercial-No Derivative Works 4.0

Fankhauser, A., McDermott, F. and Fleitmann, D. (2016) Episodic speleothem deposition tracks the terrestrial impact of millennial-scale last glacial climate variability in SW Ireland. Quaternary Science Reviews, 152. pp. 104-117. ISSN 02773791 doi: https://doi.org/10.1016/j.quascirev.2016.09.019 Available at https://centaur.reading.ac.uk/68373/

It is advisable to refer to the publisher's version if you intend to cite from the work. See Guidance on citing.

To link to this article DOI: http://dx.doi.org/10.1016/j.quascirev.2016.09.019

Publisher: Elsevier

All outputs in CentAUR are protected by Intellectual Property Rights law, including copyright law. Copyright and IPR is retained by the creators or other copyright holders. Terms and conditions for use of this material are defined in the End User Agreement.

\section{www.reading.ac.uk/centaur}


Central Archive at the University of Reading

Reading's research outputs online 


\title{
Episodic speleothem deposition tracks the terrestrial impact of millennial- scale Last Glacial climate variability in SW Ireland
}

\author{
Adelheid Fankhauser ${ }^{1,2}$, Frank McDermott ${ }^{1,3}$ and Dominik Fleitmann ${ }^{4,5}$ \\ 1. UCD School of Earth Sciences, University College Dublin, Belfield, Dublin 4, Ireland \\ 2. European Commission-Joint Research Centre (EC-JRC), Retieseweg 111, 2440 Geel, Belgium \\ 3. UCD Earth Institute, University College Dublin, Belfield, Dublin 4, Ireland. \\ 4. Department of Archaeology, School of Archaeology, Geography and Environmental Science, University of \\ Reading, Whiteknights, PO Box 227, Reading RG6 6AB, U.K. \\ 5. Institute of Geological Sciences and Oeschger Centre for Climate Change Research \\ University of Bern, Baltzerstrasse 1+3, 3012 Bern, Switzerland.
}

\begin{abstract}
Eighty four new U-Th ages are presented for twenty randomly selected broken, displaced and reworked calcite speleothems retrieved from clastic sedimentary fill and from isolated bedding-plane shelves in Crag cave (SW Ireland). The dated pre-Holocene samples span much of the last glacial, ranging in age from $85.15 \pm 0.60$ to $23.45 \pm 0.17 \mathrm{ka}$. Speleothem deposition requires the presence of liquid water, and because Crag cave is a shallow system, deposition is considered likely only when mean annual air temperatures (MAAT) exceed the freezing point of water. Deposition at this mid-latitude ocean-marginal site occurred episodically during MIS5a through to MIS2, synchronously within dating uncertainties, with the timing of Greenland Interstadials (GI). In the latter part of Marine Isotope Stage 3 (MIS3), deposition was particularly intense, consistent with regional scale climate amelioration inferred previously from radiocarbon ages for sparse MIS3 organic and freshwater surficial deposits in N. Ireland. A brief episode of speleothem deposition at c. $23.40 \pm 0.22 \mathrm{ka}$ coincides with GI-2, demonstrating the sensitivity of the site to brief climate amelioration episodes in Greenland during MIS2. Conditions favourable for speleothem deposition occurred periodically during the last glacial, indicating temperature changes of at least $10^{\circ} \mathrm{C}$ between stadials and interstadials at this mid-latitude site. Deposition ceased during Greenland Stadials (GS), including during periods of ice-rafting in the adjacent N. Atlantic Ocean (Heinrich events). Oxygen and carbon isotope ratios of the last glacial speleothems are generally elevated, reflecting non-equilibrium isotope fractionation effects. However, establishment of low $\delta^{13} \mathrm{C}$ values often occurred within a few decades of climate amelioration, indicating that biogenic $\mathrm{CO}_{2}$ production resumed rapidly at this site, particularly during MIS3. Speleothem $\delta^{18} \mathrm{O}$ variability was driven largely by long-term changes in the $\delta^{18} \mathrm{O}$ value of the adjacent North Atlantic surface water, in turn largely reflecting changes in global ice volume. In common with published speleothem datasets, warming episodes in Ireland associated with GI events typically pre-date their timing in the GICC05 and GICC05modelext time scales, but lie comfortably within the maximum counting uncertainties of these ice core age models.
\end{abstract}




\section{Introduction}

The abrupt millennial-scale Dansgaard-Oeschger (D-O) cycles that characterised the last glacial are well documented in Greenland ice cores (Johnsen et al., 1992; 2001; Dansgaard et al., 1993; Svensson et al., 2008), several marine sediment cores (e.g. Bond et al., 1993; Elliot et al., 2002; Hall et al., 2011; Eynaud et al., 2009) and in some highly-resolved terrestrial records (Voelker, 2002; Wohlfarth et al., 2008; Fletcher et al., 2010). The underlying causes of D-O variability remain controversial (Clark et al., 2002; Li et al., 2010; Dokken et al., 2013; Peltier and Vettoretti, 2014), but explanations generally involve changes in the North Atlantic meridional heat transport, sea ice extent and ice sheet dynamics, consistent with observations of anti-phase climate oscillations in Antarctica (Stocker, 1998; Wolff et al., 2010; Margari et al., 2010; WAIS Divide Project Members, 2015). Greenland Interstadial (GI) events have particularly clear expressions in Northern Hemisphere speleothems (e.g. Wang et al., 2001; Burns et al., 2003; Spötl et al., 2006; Fleitmann et al., 2009; Zhou et al., 2008; Zhao et al., 2010), but have also been detected in speleothems from the Southern Hemisphere tropics (Kanner et al., 2012). The distinct D-O patterns preserved in speleothems from the Indian/Asian monsoon regions are striking, indicating a strong teleconnection, probably linked to meridional migrations of the Intertropical Convergence Zone (ITCZ). Paradoxically, the impacts of GI events on terrestrial climatic conditions in the mid to high latitude circum-North Atlantic regions closer to Greenland, where they were first described in ice core $\delta^{18} \mathrm{O}$ records (Dansgaard et al., 1993), remain less well documented, chiefly because of the paucity of suitable terrestrial or near-shore marine pollen records with adequate temporal resolution and chronological control. Such records are particularly scarce north of $45^{\circ} \mathrm{N}$ (Fletcher et al., 2010; Sánchez Goñi and Harrison, 2010). The available precisely-dated European speleothem records for the last glacial are restricted to the Alps (Spötl et al., 2006; Boch et al., 2011; Moseley et al., 2014; Luetscher et al., 2015), southern France (Genty et al., 2003; Wainer et al., 2009; Genty et al., 2010) and northern Spain (Stoll et al., 2013). Similarly, the terrestrial climatic impacts in the mid latitude circum-Atlantic region of episodic ice-rafting associated with North Atlantic Heinrich events (Hemming, 2004) are not well quantified. Finally, while it is generally considered that the onset of warming at D-O stadial-interstadial transitions was likely synchronous between the mid- and high-latitudes of the North Atlantic region, few precisely dated records exist to test this assertion, and it is timely to revisit this question in the light of the recent discovery of centennial-scale time lags 
in the expression of GI events between Greenland and Antarctica (WAIS Divide Project Members, 2015; van Ommen, 2015).

In this study we present new U-series data for speleothems to independently constrain the timing of the onset of warming associated with GI events at a mid-latitude $\left(52^{\circ} \mathrm{N}\right)$ coastal site (Crag cave, SW Ireland). Speleothems from Crag cave offer a particular advantage for the investigation of climate variability during the last glacial because of the cave's maritime setting. Unlike some surficial terrestrial archives such as lake sediments and peat deposits, speleothems are normally quite protected from direct glacial erosion, although they can be vulnerable to destruction by meltwaters during deglaciation. Crag cave is a shallow (c. $20 \mathrm{~m}$ deep), low elevation (60 masl), sub-horizontal system developed within Carboniferous limestones in maritime SW Ireland $\left(52^{\circ} 15^{\prime} \mathrm{N}, 9^{\circ} 26^{\prime} \mathrm{W}\right)$. The cave is developed in massive grey bioclastic micrite with some coarse bioclastic calcarenites of the Lower Carboniferous Cloonagh Formation (Pracht, 1996). This Formation passes laterally into the Cracoean Reef facies which outcrops around the cave entrance. This comprises nearly pure calcite ( $>99 \%)$, with local dolomite crystals and quartz veins (Tooth and Fairchild, 2003). Close to the northeastern end of the cave, across a brecciated fault zone, the lithology changes to the darker Dirtoge Formation, a well-bedded black to dark-grey fine-grained bioclastic limestone with chert and shale horizons.

The sulphur concentration of the bedrock is low $(<0.01 \mathrm{wt} \%)$ and $\delta^{34} \mathrm{~S}$ analyses of the modern drip-waters indicate that marine aerosols dominated over bedrock dissolution as a source of drip-water sulphate (Wynn et al., 2008). Thus, while sulphide dissolution in the host-rock cannot be entirely excluded, the sulphur isotope data and the relatively low $\mathrm{S} / \mathrm{Cl}$ ratios of the modern drip-waters (Johnston, 2010) argue against sulphide dissolution as a major process at the site.

The cave's geographical position on the Atlantic margin makes it ideal for the assessment of the impact of centennial- to millennial-scale climate shifts on mid-latitude terrestrial climatic conditions during the last glacial. A two-year cave monitoring programme in the 1990s confirmed that its internal air temperature remains virtually constant at $10.4^{\circ} \mathrm{C}$, closely tracking the regional mean annual air temperature (MAAT) (McDermott et al., 1999). 
The traditional view that the southern part of Ireland remained unglaciated during the LGM (e.g. Bowen et al., 1986) has been discounted by recent studies, and it is now widely accepted that the island of Ireland was entirely glaciated by the dynamic British-Irish ice sheet (BIIS) during the Last Glacial Maximum (LGM) (Clark et al., 2012; Hughes et al., 2016). The Crag cave site in SW Ireland is nonetheless situated in a region where climatic conditions may have been influenced by ice-marginal effects, particularly in the periods leading up to and immediately following the LGM (see maps of Hughes et al., 2016).

In shallow karst systems such as Crag cave, speleothem deposition is possible only when the regional MAAT exceeds $0^{\circ} \mathrm{C}$, permitting drip-waters infiltration. Thus, pulses of speleothem deposition during the last glacial at this site are considered to be robust indicators of episodic climatic amelioration and permafrost decay permitting biogenic $\mathrm{CO}_{2}$ production the infiltration of $\mathrm{CO}_{2}$-charged soil water. On the other hand, periods of non-deposition that occur simultaneously in multiple speleothems are taken to indicate periods when MAAT values dropped below $0^{\circ} \mathrm{C}$, implying a temperature decrease of at least $10^{\circ} \mathrm{C}$ compared with present-day conditions. Speleothem deposition/non-deposition phases are thus interpreted to reflect fluctuations in the latitudinal position of the $0^{\circ} \mathrm{C}$ MAAT isotherm at this oceanic site, driven in turn by repeated meridional migrations of the Polar Front in the adjacent N. Atlantic during the last glacial.

The main objectives of this study were to: (i) assess the impact of GI events on the regional climatic conditions at this mid-latitude coastal site that is sensitive to sea-surface temperature conditions in the adjacent N. Atlantic, (ii) provide an independent chronological framework for the climatic fluctuations associated with D-O cycles, (Greenland Interstadials GI; Greenland Stadials GS) and Heinrich stadials (HS) (Bond et al., 1993; Hemming, 2004), and (iii) explore whether systematic latitudinal leads and lags can be identified in the timing of GI warming events that could in turn provide clues about their underlying causes. In order to advance these aims we present a comprehensive U-series dated speleothem dataset from Crag cave, SW Ireland. Speleothem deposition at this site appears to be highly sensitive to millennial-scale climate change during the last glacial. 


\section{Methods}

Considering that glacial meltwaters had probably dislodged and transported stalagmites in the cave, the sampling strategy was to collect a random selection of broken and dislodged speleothems that occur within the well-mixed, locally imbricated de-glacial clastic sediments in the cave. These broken and dislodged speleothems were sampled for U-series dating to evaluate the history of pre-LGM speleothem deposition in the cave. Similarly, several samples were found loose on the cave floor or on isolated rock ledges within the cave, having been apparently displaced and transported by flood meltwaters that flushed through the cave, likely following the Last Termination. A few samples (C58-2, CR001, CR002, CR004, CR007, CR008 and CR026) were found in or very close to their original depositional positions partly within the unconsolidated post glacial sedimentary fill.

The main objective of the U-series dating work was to constrain the upper (younger) and lower (older) limits of hiatus-bound depositional phases within multiple speleothems. Following observation of the depositional phases using petrographic thin sections and thick back-lit slices, samples were selected for dating (c. 50-100 mg) by drilling at points along the stalagmite growth axes and in flowstones perpendicular to the layering. Although the stalagmites were generally not in-situ, is was relatively easy to establish their growth axis based on the overall shape of the samples and on the geometry of the laminae after the samples had been sawn in half parallel to their long axes. Sample powders were weighed and spiked using a calibrated mixed ${ }^{233} \mathrm{U} /{ }^{236} \mathrm{U} / 229 \mathrm{Th}$ isotope tracer. Following sample dissolution in low-blank nitric acid and overnight sample-spike equilibration, chemical separation of uranium and thorium was carried out by anion exchange chromatography using standard methods.

All measurements for the U-series work were carried out using a high-resolution multicollector inductively coupled plasma mass-spectrometer (ThermoFisher Neptune ${ }^{\circledR}$ multicollector equipped with an Aridus ${ }^{\circledR}$ desolvation nebuliser) at the National Centre for Isotope Geochemistry, University College Dublin. ${ }^{238} U /{ }^{236} U$ and ${ }^{233} U /{ }^{236} U$ isotope ratios were measured simultaneously using Faraday collectors, and the lower intensity of the ${ }^{234} \mathrm{U}$ ion beam was measured using the secondary electron multiplier (SEM) in the central collector of this instrument. Calibration of the SEM/Faraday yield was achieved with a sample-standard bracketing method using the certified ${ }^{235} \mathrm{U}^{238} \mathrm{U}$ ratio of the IRMM-3184 standard and an 'in- 
house' uranium standard. A mass-fractionation correction was applied to the measured uranium isotope ratios based on the certified ${ }^{233} \mathrm{U} /{ }^{236} \mathrm{U}$ ratio of the mixed spike. For thorium, ${ }^{230} \mathrm{Th} /{ }^{232} \mathrm{Th},{ }^{230} \mathrm{Th} /{ }^{232} \mathrm{Th}$ and ${ }^{230} \mathrm{Th} /{ }^{229} \mathrm{Th}$ ratios were measured in cycles using the SEM in the

central collector and Faraday collectors for ${ }^{232} \mathrm{Th}$, if applicable. A standard-sample bracketing using a uranium standard was applied for the mass fractionation correction and for SEM/Faraday yield calibration. With the exception of samples CR005 U-Th-2 and C58-2 UTh-5, all $2 \sigma$ relative errors are less than $1 \%$. For all ages, a correction for inherited (detrital) ${ }^{230} \mathrm{Th}$ was applied using a ${ }^{230} \mathrm{Th} /{ }^{232} \mathrm{Th}$ activity ratio of $0.8 \pm 0.4$ (Richards and Dorale, 2003), but for most samples this correction was negligible due to very high ${ }^{230} \mathrm{Th} /{ }^{232} \mathrm{Th}$ ratios. The final age results are given in ka before present using the reference year 2000 AD (b2k) (Table $1)$.

Oxygen and carbon isotopes were analysed on calcite sub-samples drilled along the growth axis of the speleothems at a spatial resolution ranging from $0.5 \mathrm{~mm}$ (CR025) to $2 \mathrm{~mm}$ (C58-2), and in some samples only pointwise, adjusted as necessary around the sampling points for UTh measurements (CR008, CR020). The analysis were performed at the Institute of Geological Sciences at the University of Bern, Switzerland, using the methods described previously (Fleitmann et al., 2009). 150-200 $\mu \mathrm{g}$ of powder per sub-sample was measured using a Finnigan Delta V Advantage gas source mass spectrometer, and an internal laboratory standard calibrated to the Vienna Pee Dee Belemnite-standard (VPDB). The results are expressed in the delta $(\delta)$ notation in per-mil (\%o) deviation between the sample and the VPDB-standard. Analytical precisions of $\delta^{13} \mathrm{C}$ and $\delta^{18} \mathrm{O}$ measurements are $0.06 \%$ and $0.07 \%$, respectively ( $1 \sigma$-error).

Where appropriate, our interpretation of the U-series dates and accompanying stable isotope data was supported by textural analysis of the speleothem crystal fabrics based on the scheme of Frisia (2015).

\section{Results}

Stalagmites from Crag cave are characterised by high uranium contents (typically several ppm and exceptionally more than $30 \mathrm{ppm}$, Table 1) which facilitates precise U-series dating. In total eighty four U-Th ages (Table 1) were measured to constrain the major depositional 
phases within twenty speleothems from the cave (Figs. 1 and 2). Most of these re-worked speleothems date from the last glacial period, with only one example from the Last Interglacial (MIS 5e and 5c, not discussed here). The last glacial dates range from $85.15 \pm$ $0.60 \mathrm{ka}$ (sample CR023, Fig. 2) to $11.68 \pm 0.15 \mathrm{ka}$ (sample CR006). The new data reveal multiple episodes of speleothem deposition during Marine Isotope Stages (MIS) 5a through to MIS2, typically recorded contemporaneously within several speleothems (Table 1, Figs. 1 and 2).

For the last glacial period of interest here, speleothem deposition at Crag cave commenced during MIS5a at $85.15 \pm 0.60 \mathrm{ka}$ (sample CR023, Fig. 2) and the youngest Late Glacial age is $23.35 \pm 0.10 \mathrm{ka}$ recorded by a thin layer of carbonate deposited near the top of sample CR025 (Fig. 1). In addition, several post-glacial ages are recorded within four small flowstones (samples CR001, 007, 002, 004 see upper left hand side of Fig. 2). A single flowstone (sample CR006, Fig. 2) yields a date of $11.68 \pm 0.15 \mathrm{ka}$ and is within error of the start of the Holocene $(11.70 \mathrm{ka})$ in the recently defined INTIMATE event stratigraphy (Rasmussen et al., 2014).

$\delta^{13} \mathrm{C}$ varies from -10.0 to $2.0 \%$ in a wide range of speleothems from Crag cave and is typically higher in last glacial samples compared with the Holocene samples (Fig. 4). $\delta^{18} \mathrm{O}$ in last glacial speleothems from Crag cave ranges from -2.2 to $1.6 \%$ (Fig. 5). By comparison, $\delta^{18} \mathrm{O}$ in the late Holocene portion of a stalagmite from Crag cave (CC3), sampled at a similar spatial resolution ranges from -1.8 to $-4.6 \%$ (McDermott et al., 1999) and is markedly lower than in most of the last glacial samples studied here. The stable isotope records of sample CR025 and C58-2 are adjusted to the U-Th ages by linear interpolation or extrapolation within the depositional intervals, being aware that this is an approximation that may mask depositional rate changes. Nevertheless, it shows the pattern and correlation of the $\delta^{18} \mathrm{O}$ and $\delta^{13} \mathrm{C}$ values within the depositional intervals. Most striking are pronounced increases in the $\delta^{13} \mathrm{C}$ and $\delta^{18} \mathrm{O}$ values that occur within a few decades before the termination of several depositional intervals (e.g. GI-4, GI-5.2, GI-6 and GI-11, Figs. S2 and S3).

The speleothems reveal a variety of calcite fabrics (Frisia, 2015). The most striking feature is the difference in fabrics between samples deposited during most of the last glacial and those 
deposited close to the beginning and end of the Younger Dryas. Thus, whereas most of the last glacial stalagmites (e.g. samples CR005, 020, 032, 034, 035-A, 035B; Fig. 2) exhibit a dense and compact columnar texture, four flowstones deposited during the Younger Dryas exhibit a porous dendritic fabric that is quite unlike that of the last glacial samples. Sample CR006, dated at $11.68 \pm 0.15 \mathrm{ka}$ (beginning of Holocene) shows a return to more compact columnar calcite textures, in marked contrast with the porous dendritic textures of the Younger Dryas samples.

One characteristic of many of the samples is that they consist of several depositional phases clearly divided by hiatuses (Figs. 1 and 2). In general, these hiatuses contain visible layers of fine detrital material (clay). At some hiatuses, fragments of broken speleothems are incorporated in the lowest part of the following depositional phase, for example in samples CR005, 008 and 026. Some of these samples still have unconsolidated, fine grained siliclastic sediment and fragments of stalactites attached to their basal surfaces, e.g C58-2, CR005, 023 and 025 , indicating that they were deposited on soft sediment. In the case of stalagmite CR025, unconsolidated clastic sediments appear to have built up episodically around the stalagmite during periods when calcite deposition did not occur, resulting in a marked tapering out of the growth laminae towards the margins in cross-section (Fig. 1). Multiple depositional intervals, accompanied by offsets in growth axes and changes in the width of the central depositional area around the growth axes following hiatuses are common in these samples (e.g. CR025, 035-A, 032). However, the samples seldom show a clear layering which would permit a more detailed analysis of the character of the hiatuses. The classification scheme of Railsback et al. (2011) was applied where possible, and this approach indicates that the tops of the depositional phases corresponding to GI-10, GI-8, GI-6 and GI-5.2 in sample CR025, and GI-8 in C58-2 can be attributed to surface type L, representing a decrease of the sample diameter due to lower drip rates. However we cannot preclude the possibility that the upper surface of the interval corresponding with GI-8 in CR025 has been partially eroded on one side (Fig. 1).

The discontinuous nature of the samples that typically comprise several hiatus-bound depositional intervals also results in quite variable growth rates, even within a single sample. Intervals of several centimetre speleothem deposition where U-Th ages are almost identical within each-others uncertainties occur, indicating very fast deposition within a few hundred 
years, and thus growth rates of $>100 \mathrm{~mm} / \mathrm{ka}$, (eg. GI-5.2 and GI-6 sample C58-2; GI-5.2 and GI-6 in CR025, sample CR035-B). By contrast, other intervals exhibit growth rates that are 5 to10 times slower (eg. GI-4 in CR025, GI-7 in C58-2).

\section{Discussion}

\subsection{Timing of speleothem deposition during the last glacial at Crag cave}

Phases of speleothem deposition were found to be linked temporally with the Greenland Interstadials (GI) GI-21 through to GI-2 (Fig. 3). As discussed below, deposition continued episodically during MIS5a through to MIS2, synchronously with GI events, well within their dating uncertainties, based on the maximum counting errors of the NGRIP spliced GICC05/ss09sea age model (Svensson et al., 2008, Wolff et al., 2010) and the extended INTIMATE event stratigraphy for the last glacial (Rasmussen et al., 2014), (Table 2). GI-21 is represented by nine U-series dates from four independent speleothems (CR005, CR035-A, CR035B and CR023; Fig. 3, Table 1), spanning the range $85.15 \pm 0.60 \mathrm{ka}$ to $79.43 \pm 0.47 \mathrm{ka}$. Thus, the onset of deposition at $85.15 \pm 0.60 \mathrm{ka}$ in CR023 is in excellent agreement with the timing of GI-21.2 at $85.06 \mathrm{ka}$ in the INTIMATE event stratigraphy (Rasmussen et al., 2014). The relatively long-lived GI-21.1 (Rasmussen et al., 2014) is represented by eight U-series dates from three speleothem samples (CR005, CR035-A, CR035B) with ages in the range $84.30 \pm 0.47 \mathrm{ka}$ to $79.43 \pm 0.47 \mathrm{ka}$.

Deposition that occurred immediately following a clear petrographic hiatus in flowstone CR005 (Fig. 2) is dated by sample CR005 U-Th-5 at $73.09 \pm 0.67 \mathrm{ka}$ and is interpreted to represent the start of GI-19.2 at $72.34 \mathrm{ka}$ in the INTIMATE event stratigraphy (Rasmussen et al., 2014). GI-19.2 is also marked by deposition in samples CR032 and CR029 with ages of $72.58 \pm 0.33$ and $72.45 \pm 0.44$ ka respectively (Table 1, Fig. 2). It should be noted that the age uncertainties attached to this part of the INTIMATE event stratigraphy are probably relatively large (>2.5kyr)

Deposition at $65.65 \pm 0.33$ ka near the base of sample CR032 (Fig. 2) may be linked to GI-18, but its timing is considerably older (by about $1.5 \mathrm{ka}$ ) compared with GI-18 in the INTIMATE event stratigraphy at $64.1 \mathrm{ka}$. We note that an early onset in GI-18 at c. $65 \mathrm{ka}$ also seems to be preserved in the Hulu Cave record (Wang et al. 2001, Fig. 3E), but the shift in $\delta^{18} \mathrm{O}$ is gradual and muted, making the transition difficult to define. As discussed below, stalagmite 
CR032 is not considered to be a reliable indicator of the start of GI-18 (or other events) because of the difficulty in defining discrete depositional phases in this particular stalagmite (Fig. 2), in contrast with the clearly defined hiatus-bound visible depositional phases in the exemplar stalagmites CR025 and C58-2 (Fig. 1). Deposition recorded by CR028 U-Th-1 at $58.40 \pm 0.43 \mathrm{ka}$ is similar to the timing of GI-16.2 in the extended INTIMATE event stratigraphy (Rasmussen et al., 2014) at $58.28 \mathrm{ka}$, and is comfortably within the relatively large quoted $2 \sigma$ uncertainty of $2.51 \mathrm{kyr}$ for the INTIMATE stratigraphy at this time (Table 2).

Events GI-14 and GI-13 are not well represented by speleothem deposition in the Crag cave samples, apart from a single ex-situ stalactite (CR008-B; Figs. 2 and 3) dated to $50.53 \pm 0.35$ $\mathrm{ka}$, probably corresponding to GI-13c at $49.28 \pm 2.03 \mathrm{ka}$ in the INTIMATE event stratigraphy (Table 2). GI-13c is a minor interstadial (North Greenland Ice Core Project Members, 2004; Svensson et al., 2008; Wolff et al., 2010; Rasmussen et al., 2014), but the apparent absence of deposition in the period $56.76 \pm 0.32$ (CR032) to $50.53 \pm 0.35 \mathrm{ka}$ is unexpected, because GI14 is a relatively long and well-defined event in Greenland and is represented in speleothems from Kleegruben Cave in the Austrian Alps (Spötl et al., 2006). Nonetheless, we note that GI-14 is also poorly represented in speleothems from Villars Cave in SW France $\left(45^{\circ} 30^{\prime} \mathrm{N}\right.$, 05'E) (Genty et al., 2003; Wainer et al., 2009; Genty et al., 2010). At Villars Cave, a clear depositional hiatus bracketed by two U-series ages $(55.94 \pm 0.58$ and $51.78 \pm 0.88$ was documented in a stalagmite (Vil 9), that otherwise grew continuously throughout MIS3 (Genty et al., 2003). While the paucity of deposition in the period between c. $56.8 \mathrm{ka}$ and $50.5 \mathrm{ka}$, much of which is represented by the relatively long-lived GI-14 in Greenland, may reflect local site-specific effects (e.g. hydrological routing), the occurrence of a coeval depositional hiatus at Villars Cave may indicate an overarching climatic control at these midlatitude sites that are particularly sensitive to conditions in the N. Atlantic. It is also noteworthy in this regard that the beginning of this long depositional hiatus coincides with cooling event HS-5a, recognised in marine sediment cores from the Labrador Sea (Rachid et al., 2003), the Irminger Sea (van Kreveld et al., 2000) and the N. Atlantic at c. 56 ka (LynchStieglitz et al., 2014). Crucially, high resolution cores from the Iberian margin and the Bay of Biscay (McManus et al., 2001) also preserve clear evidence for cooling at this time (c. $56 \mathrm{ka}$ ), with abrupt increases in abundances of the polar planktonic foraminifera N. pachyderma (s) to c. $80 \%$ in core MD04-2845 (Bay of Biscay) and c. 50\% in cores MD99-2331 (Sánchez Goñi et al, 2008) and SU92-03 (Salgueiro et al., 2010) from the NW Iberian margin (Fig. S1). The 
absence of speleothem deposition during the time period 57-50 ka (GS-16.1 through to the quasi-stadial GS-14) suggests that despite its long duration in Greenland, terrestrial climatic amelioration at $52^{\circ} \mathrm{N}$ during GI-14 was insufficient to permit speleothem deposition, although we cannot rule out alternative explanations such as cave flooding at this time.

By contrast with the paucity of deposition during the early part of MIS3 at this site, a period of intense speleothem deposition occurred during the latter part of MIS3, associated with multiple GI events, GI-12 through to GI-3, with the intervening GS events represented by depositional breaks (Figs. 1 and 2). Distinctive, hiatus-bound episodes of speleothem deposition are particularly well defined within MIS3 within the two key stalagmites (CR025 and CR58-2, Fig. 1). Thus, sample CR025 contains nine visible hiatus-bound MIS3 depositional intervals constrained by 24 U-Th ages (Fig. 1). Sample C58-2 contains seven such depositional phases, six of which are also represented in CR025, constrained by a further 25 U-Th ages (Fig. $1 \&$ Table 1). Several independent speleothems from the site show episodic deposition during MIS3 (Fig. 3B, Fig. 2), indicating an overarching external climatic and not a localised hydrological control on speleothem deposition. Episodic deposition during the latter part of MIS3 is consistent with previously described but poorly resolved and dated evidence for MIS3 interstadials in Britain and Ireland (Coope et al., 1977; Woodman et al., 1997; Colhoun et al., 1972). Evidence from surface sediments for climate amelioration episodes during MIS3 is sparse in Ireland, but organic-rich silts sampled from between two tills at Derryvree (Co. Fermanagh, N. Ireland) yielded calibrated radiocarbon ages of 31.7 to 36.9 ka (Colhoun et al., 1972), corresponding approximately to GI-8 to GI-5. Similarly, organic material from a lacustrine deposit at Greenagho (Co. Fermanagh, N. Ireland) produced a calibrated radiocarbon age of 37.2 to $35.7 \mathrm{ka}$, likely linked to GI-8 or GI-7. Evidence for the high sensitivity of Crag cave site to even brief periods of climate amelioration, likely linked to temporary northward retreats of the N. Atlantic Polar Front during the last glacial, is neatly provided by a brief phase of deposition at $23.45 \pm 0.17 \mathrm{ka}$ and $23.35 \pm 0.10 \mathrm{ka}$ (overlapping ages), reflecting the weak and short-lived GI-2.2 event within MIS2 (Fig. 3, Table 2), dated in the Greenland ice at $23.34 \pm 0.60 \mathrm{ka}$ (Svensson et al., 2008; Rasmussen et al., 2014).

Overall we argue that well-defined phases of deposition, highlighted by the vertical yellow bars in Fig. 3, typically fall within the error limits of the chronology for GI events (Svensson 
et al., 2008; Rasmussen et al., 2014) and reflect brief periods of climate amelioration in SW Ireland when the MAAT exceeded $0^{\circ} \mathrm{C}$, allowing the presence of liquid water in the cave, along with sufficient biogenic $\mathrm{CO}_{2}$ production to permit speleothem deposition.

Speleothem deposition associated with GI-20c (CR035-A U-Th-3 dated to $77.05 \pm 0.61 \mathrm{ka}$ appears to pre-date its timing in the NGRIP-based INTIMATE event $\delta^{18} \mathrm{O}$ profile (c. 76.44 ka) by up to 610 years (Fig. 3, Table 1), but is well within the relatively large $2 \sigma$ uncertainties attached to this extended part of the INTIMATE event stratigraphy (Rasmussen et al., 2014).

Because late glacial speleothem deposition at Crag cave was strongly discontinuous and episodic, the mid-point $\delta^{18} \mathrm{O}$ transitions between stadial and interstadial conditions that are conventionally used to correlate with GI events in the Greenland ice records (e.g. Austin and Hibbert, 2012) cannot be distinguished in our dataset, unlike at other European cave sites where speleothem deposition was apparently continuous through at least some of the Greenland Stadials (e.g. Genty et al., 2010; Boch et al., 2011; Moseley et al., 2014). However, the evidence for a temporal association between depositional phases at Crag cave and GI events is overwhelming and to our knowledge is unique for these northerly midlatitudes. Our preferred correlations between the last glacial depositional phases in Crag cave and the extended INTIMATE event stratigraphy (Rasmussen et al., 2014) is shown in Table 2.

\subsection{Timing of non-depositional phases during the last glacial at Crag cave}

Episodes of non-deposition also occurred synchronously in several speleothems from Crag cave. Fig. 3 also illustrates the timing of depositional hiatuses in relation to the age of Heinrich stadials (HS) from published datasets. Depositional hiatuses in our speleothem dataset offer independent tight constraints on the timing of Heinrich stadials HS-6 to HS-2 (Fig. 3F). The beginning of HS-6 is constrained by the short depositional pulse at $65.65 \pm$ $0.33 \mathrm{ka}$ corresponding to a thin grey calcite layer in CR032 (Figs. 2 \& 3) that exhibits particularly high $\delta^{13} \mathrm{C}$ (discussed below), reflecting kinetic isotope fractionation (McDermott et al., 1999). As discussed below, this may suggest marginal conditions for speleothem deposition at this time. Deposition recommenced in CR032 at $60.83 \pm 0.37 \mathrm{ka}$ (Fig. 2), marking the end of HS-6 at 60.1 ka (Sánchez Goñi and Harrison, 2010) and the onset of GI-17 at $59.44 \pm 2.57 \mathrm{ka}$ (Svensson et al., 2008; Wolff et al., 2010; Rasmussen et al., 2014). 
Cooling associated with HS-5 is recorded as a depositional break between $50.53 \pm 0.35 \mathrm{ka}$ (CR008-B) and $47.90 \pm 0.24 \mathrm{ka}$ (CR032, Fig. 2), in agreement with its independently inferred timing of 50 to $47 \mathrm{ka}$ (Sánchez Goñi and Harrison, 2010) and the start of GI-12 at $46.86 \pm$ $1.91 \mathrm{ka}$ (Rasmussen et al., 2014). We note that speleothem deposition continued slowly during this cold interval at Kleegruben Cave in the Austrian Alps (Spötl et al., 2006), indicating a less sensitive threshold response to N. Atlantic cooling during HS-5 at this Alpine site compared with the ocean-proximal Crag cave. HS-4 is bracketed by dates of $40.59 \pm 0.18$ ka (CR025 U-Th-26) and $38.35 \pm 0.22$ ka (C58-2 U-Th-9), in excellent agreement with independent estimates for the HS-4 limits of 40.2 to 38.3 ka (Sánchez Goñi and Harrison, 2010), and the published ages for its bracketing GI-9 and GI-8 events at $40.16 \pm 1.58 \mathrm{ka}$ and $38.22 \pm 1.45$ ka respectively (Svensson et al., 2008; Rasmussen et al., 2014). We interpret the paucity of speleothem deposition at Crag cave during HS-4 as indicative of strong regionalscale cooling, consistent with findings that the Polar Front extended as far south as the Iberian Peninsula $\left(42^{\circ} \mathrm{N}\right)$ during HS-4 (Eynaud et al., 2009; Lynch-Stieglitz et al., 2014). Mean annual air temperatures at least $10^{\circ} \mathrm{C}$ lower than at present at this site are therefore inferred during the Heinrich stadials.

Cooling associated with HS-3 occurs between $32.35 \pm 0.15$ ka (C58-2, U-Th-23) to $29.61 \pm$ $0.12 \mathrm{ka}$ (CR025, U-Th-18), consistent with the start of GS-5 at 32.5 $\pm 1.1 \mathrm{ka}$ (Rasmussen et al., 2014). A short centennial-scale depositional interval occurs from $30.92 \pm 0.13$ to $30.79 \pm$ 0.13 (C58-2, Fig. 1) interpreted to reflect a contemporaneous weak warm event (GI-5.1) in NGRIP, further demonstrating the sensitivity of this location and karst system to short-lived warming events. The $4.47 \mathrm{kyr}$ hiatus ( $27.92 \pm 0.16$ to $23.45 \pm 0.17 \mathrm{ka}$ ) near the top of sample CR025 (Fig. 1) is linked to the stadial containing Heinrich event 2, consistent with published chronologies (Fig. 3), although its c. 2.5 kyr longer duration inferred from the Crag cave results may reflect the site's proximity to the British Irish Ice Sheet (BIIS) which was close to its maximum extent at that time (e.g. Clark et al., 2012; Hughes et al., 2016). In summary, all of the Heinrich stadials are marked by drastically reduced or no deposition indicative of cold dry conditions and are interpreted to reflect a Polar Front position south of $52^{\circ} \mathrm{N}$. The new data presented here tightens the chronology of regional-scale cooling episodes in this region of N.W. Europe, linked to Heinrich events and also has implications for the dynamics of the southern margin of the British-Irish Ice Sheet (BIIS) as discussed below. 


\subsection{Deposition during the Younger Dryas and the start of the Holocene}

While the main focus of this paper is on the last glacial, here we briefly discuss the evidence for speleothem deposition and climatic conditions during the Younger Dryas (YD) period and the beginning of the Holocene. As mentioned above, four small flowstones (CR001, 007, 004 and 002; Fig. 2) show evidence for deposition during the YD. The lower surfaces of all four flowstones are flat and smooth. The undersides of samples CR001 and 007 additionally show rims and knobs formed by calcite infilling of desiccation cracks and drip tubes. These are interpreted to reflect flowstone deposition on desiccated fine-grained cave sediment that had originally been deposited in standing water. All of these samples have a 'dirty' brown colour and exhibit porous dendritic fabrics, in contrast with the compact columnar fabrics that are common in the last glacial samples. In the interpretative scheme of Frisia (2015), such dendritic fabrics are indicative of strong degassing and the presence of particulate matter, consistent with their deposition as flowstones, the obvious presence of brown detrital material and their low $\left({ }^{230} \mathrm{Th} /{ }^{232} \mathrm{Th}\right.$ ) ratios (Table 1). The texture of flowstone CR006, dated at $11.68 \pm$ $0.15 \mathrm{ka}$ is quite different to that of the YD samples showing a return to cleaner, more compact columnar calcite textures, in marked contrast with the porous dendritic textures developed in the YD samples. This change is also reflected in the higher $\left({ }^{230} \mathrm{Th} /{ }^{232} \mathrm{Th}\right)$ ratio of this sample (c. 300), reflecting its cleaner, more compact fabric and lower amounts of clay mineral contamination.

\subsection{Interpretation of Oxygen and carbon isotope variability}

Speleothem oxygen and carbon isotope data provide further insights into the impacts of millennial-scale climate variability on terrestrial conditions and ecosystems during the last glacial. A wide range of climate-related factors are known to influence speleothem $\delta^{13} \mathrm{C}$ (Baker et al., 1997; Genty et al., 2001; McDermott, 2004; Rudzka et al., 2011). In general, low $\delta^{13} \mathrm{C}$ values indicate that cave drip-waters equilibrated with soil $\mathrm{CO}_{2}$ produced by biological processes, involving some combination of root respiration by extant vegetation and microbial decomposition of older stored organic matter in the soil, and possibly in the epikarst and vadose zones. In the presence of $\mathrm{C} 3$ plants, the $\delta^{13} \mathrm{C}$ of soil $\mathrm{CO}_{2}$ is typically in the range 26 to $-20 \%$ o (Baker et al., 1997). $\delta^{13} \mathrm{C}$ values in the range -14 to $-6 \%$ are therefore expected for speleothems in these regions, taking into account the equilibrium isotope fractionation 
factors between soil $\mathrm{CO}_{2}$ and the dissolved inorganic carbon (DIC) carried downwards by percolating soil waters, and the additional small $\delta^{13} \mathrm{C}$ fractionation that occurs when speleothem calcite is precipitated by degassing in the cave (Mook et al., 1974; Salomons and Mook, 1986). Low $\delta^{13} \mathrm{C}$ values in speleothems deposited in Crag cave during MIS3 and 5a, particularly in GI-5 and GI-6 are noteworthy, because they indicate conditions favourable for the presence of vegetation above the cave, and inputs from biogenic soil-derived carbon. Importantly, $\delta^{13} \mathrm{C}$ attains relatively low values of $<-8$ during GI-5.2 and GI-6 in both samples CR025 and C58-2 (Fig. 4), similar to those observed in a Holocene stalagmite (CC3) from this cave (McDermott et al., 1999), and well within the range expected for a site where C3 vegetation occurs. The observation that even the earliest calcite that was deposited following the stadials in MIS3 exhibits low $\delta^{13} \mathrm{C}$ values $(<-8 \%$ ) could indicate the rapid reestablishment of vegetation when climatic conditions ameliorated (e.g. GI-5.2 and GI-6 Figures S2 and S3). An alternative interpretation, consistent with the rapidity with which low $\delta^{13} \mathrm{C}$ values are re-established after climate amelioration (e.g. likely within decades to a century in the cases of GI-4, GI-5.2, GI-6, GI-7, GI-8 and GI-11, Fig. S3) is that organic material that was stored in frozen soils and possibly the epikarst zone of the cave was rapidly remobilised by microbial decomposition immediately after the onset of warming. Either explanation requires rapid local warming at the onset of these interstadials.

As discussed below, the interpretation of speleothem $\delta^{18} \mathrm{O}$ variability in terms of a single climate variable is usually not possible because of the multiplicity of factors that influence speleothem $\delta^{18} \mathrm{O}$ (e.g. vapour source and transport effects, air temperature and site-specific effects). Nonetheless, clear differences can be observed between the last glacial and Holocene samples that are discussed below.

In detail, $\delta^{18} \mathrm{O}$ and $\delta^{13} \mathrm{C}$ are strongly correlated in the last glacial samples, indicating the prevalence of kinetic isotope enrichment processes (Fig. 6). The data exhibit two sub-parallel arrays, with the offset to high $\delta^{18} \mathrm{O}$ in the last glacial samples attributable to the ice-volume influence on North Atlantic $\delta^{18} \mathrm{O}$, the predominant vapour source for meteoric precipitation at this site. Importantly, it can be argued that samples with the lowest $\delta^{13} \mathrm{C}(<-4 \%$ ) are least affected by isotope disequilibrium effects, and $\delta^{18} \mathrm{O}$ in these samples exhibits a long-term shift to higher values during the course of the last glacial (Fig. 5b), closely tracking the $\delta^{18} \mathrm{O}$ of the 
N. Atlantic inferred from planktonic foraminifera $\delta^{18} \mathrm{O}$ data from core ODP $980\left(55^{\circ} 29^{\prime} \mathrm{N}\right.$, $14^{\circ} 42^{\prime} \mathrm{W}$; Supplementary Fig. S1). This indicates a direct link between Atlantic Ocean surface water and the Crag cave speleothem $\delta^{18} \mathrm{O}$ signal, suggesting that the water vapour source, and not local air temperature provided the first-order control on speleothem $\delta^{18} \mathrm{O}$ on these timescales.

\subsection{Implications for the NGRIP Chronology}

The data provide new insights into the terrestrial climatic impact of millennial-scale variability linked to Greenland Interstadials (GI), with a resolution and chronological control that was hitherto unattainable for terrestrial records north of $50^{\circ} \mathrm{N}$. Despite the relatively high latitude of the cave site and its proximity to the inferred position of the British Irish Ice Sheet (BIIS) during much of the last glacial, multiple phases of speleothem deposition are apparently synchronous (within dating uncertainties) with GI events reflecting the presence of liquid water in the cave, and MAAT above $0^{\circ} \mathrm{C}$ at these times. Well-defined hiatuses indicate MAAT $<0^{\circ} \mathrm{C}$, and Polar Front incursions south of $52^{\circ} \mathrm{N}$ are inferred, not only during Heinrich stadials (HS), but also repeatedly during Greenland Stadials (GS). Our results also suggest that the soil ecosystem responded rapidly (within a few decades, Figure S3) to repeated climate amelioration during GI events throughout the entire glacial, producing sufficient $\mathrm{CO}_{2}$ to generate the $\mathrm{CaCO}_{3}$-saturated drip-waters required for speleothem deposition.

In Fig. 7, the timing of the beginning of the hiatus-linked depositional phases in Crag cave speleothems are compared in with the timing of GI events in Greenland (Svensson et al., 2008; Rasmussen et al., 2014). Whilst recognising that oxygen isotope-transition mid-points are used to define the onset of GI events in the Greenland ice core records, the transitions are extremely rapid (typically a few decades), and so their comparison with the onset of deposition at Crag cave is relevant to discussions about possible leads, lags or chronological errors. As observed previously in studies of the timing of GI events in speleothems from Hulu Cave (Wang et al., 2001), Sofular Cave (Fleitmann et al., 2009), Kleegruben Cave (Spötl et al., 2006), Sanxing Cave (Jiang et al., 2016) and the NALPS record (Boch et al., 2011; Moseley et al., 2014), the onset of depositional phases at Crag cave linked to GI events typically pre-dates the Greenland chronology by several centuries, but all of the differences lie within the 1-sigma ice core counting errors (Svensson et al., 2008; Rasmussen et al., 2014). 
In detail the age discrepancies changes from virtually zero at GI-1 to c. 750 years at GI-4 for the Hulu record (Fig. 7), returning to almost zero close to $85 \mathrm{ka}$ (GI-21).

In general, the onset of speleothem deposition at Crag cave in response to GI events occurs earlier than the timing of these events in the INTIMATE event stratigraphy in the period c. 65-25 ka based on the GICC05modelext time scale. Similar observations have been made for speleothems from Hulu- and Sofular caves (Wang et al., 2001; Fleitmann et al., 2009) and caves in the northern European Alps (Boch et al., 2011; Moseley et al., 2014; 2015), but we emphasise that the age offsets are always within the $2 \sigma$ maximum counting uncertainty limits of the NGRIP chronology and indeed, with the exception of GIU-4 are typically within the $1 \sigma$ limits (Fig. 7). The mismatch between the NGRIP and Hulu chronology has recently prompted the application of an ad-hoc correction factor (x 1.0063; WAIS Divide Project Members, 2015) in order to correct for possible missing layers in the NGRIP record. We note that for the period before 60ka (e.g. GI events 21-20), the mismatch is negligible, but this in part reflects the effect of subtracting 705 years in the period before 60ka (Wolff et al., 2010) in the underpinning GICC05modelext time scale.

It is also noteworthy that the available speleothem constraints from Crag cave, Hulu cave and Sofular cave for the timing of some GI events (e.g. GI-4, GI-11) are in particularly good agreement (Fig. 7) and this suggests that the NGRIP chronology may be too young, but probably by less than 500 years during MIS3. While the timing offsets relative to NGRIP exhibited by the Hulu, Sofular and Crag cave data are suggestive of a common trend (decreasing age offset relative to NGRIP between GI-11 and GI-8, followed by an increasing offset between GI events 8 and 4, the differences are small and are typically close to or within the dating error bars for the speleothem U-series dates. The relatively large age difference for the onset of GI-4 in the Crag, Hulu and Sofular speleothem records (Fig. 7) merits further investigation as it may imply delayed warming in Greenland relative to the lower latitudes immediately after Heinrich event H4.

\subsection{Implications for British-Irish Ice Sheet (BIIS) dynamics}

Evidence for abundant speleothems deposition at Crag cave between 38-34 ka and 32-30 ka is in good agreement with a recent reconstruction of the BIIS margin (Clark et al., 2012; Hughes et al., 2016) that implies ice-free conditions in southern Ireland during this part of late MIS3. 
Speleothem deposition at the Crag site in the period around 29-28 ka (e.g. dates at $27.92 \pm$ $0.16 \mathrm{ka}, 28.21 \pm 0.11 \mathrm{ka}$ and $29.18 \pm 0.17 \mathrm{ka}$ ) argues against an extensive regional scale ice sheet cover in this interval, as implied by a recent BIIS reconstruction (Hughes et al., 2016), but is consistent with a view that maximum ice sheet limits did not occur until around $27 \mathrm{ka}$ in the region offshore SW Ireland (Clark et al., 2012). Evidence for a brief phase of speleothem deposition at c. $23.4 \mathrm{ka}$ at the top of speleothem CR025 (Fig. 1) suggests that the climatic amelioration associated with GI-2 may have resulted in a temporary retreat of the BIIS at this site in SW Ireland, again perhaps implying a more dynamic south-western margin or earlier establishment of an ice-free corridor north of the mountainous area in SW Ireland than implied in some recent reconstructions. Deposition at c. $23.4 \mathrm{ka}$ is consistent with early (24$21 \mathrm{ka}$ ) thinning of the Irish Ice Sheet (Ballantyne and Stone, 2015).

\section{Summary}

U-series ages for a wide selection of randomly sampled broken and reworked speleothems from clastic sediments of Crag cave site indicate that speleothem deposition was strongly episodic during the last glacial. Crucially, these depositional phases are demonstrably linked to intervals of regional-scale climatic amelioration associated with GIs. In general, the onset of speleothem depositional phases at Crag cave coincides within chronological uncertainties with the previously published start dates for multiple GI events throughout the past 85kyrs. By virtue of the Crag cave's mid-latitude Atlantic margin position and its sensitive threshold deposition/no-deposition response during the last glacial, the new data permit an unprecedentedly detailed reconstruction of the repeated millennial-scale Polar Front advances and retreats associated with climate perturbations during the last glacial, at temporal resolutions that were hitherto unattainable.

There is evidence that the onset of speleothem depositional phases may have predated the timing of linked GIs, typically by up to a few centuries, and exceptionally by up to $1.5 \mathrm{kyr}$ in the case of GI-18, although further work is required to investigate this. Similar systematic offsets to older ages relative to equivalent interstadial events in the NGRIP chronology have been observed elsewhere in speleothem records from the Northern Hemisphere (e.g. Hulu Cave, Kleegruben Cave, Sofular Cave). This may indicate that at least some intervals of the Greenland and INTIMATE event chronology are too young, although we emphasise that the 
age differences are small and lie within the quoted maximum counting uncertainties of the NGRIP chronology.

There is also strong evidence that conditions at the cave site during the Heinrich stadials were not conducive to speleothem deposition. The new dates place tight constraints on the timing of cooling episodes that are linked to Heinrich stadials $\mathrm{H} 6$ to $\mathrm{H} 2$. We interpret the absence of deposition during these cold intervals as reflecting the presence of permafrost, likely linked to southward migration of the polar front in the adjacent North Atlantic Ocean. The evidence for Greenland-synchronous warming and cooling events at this mid-latitude site, coupled with the observation that some Heinrich stadials were associated with only muted changes in $\mathrm{N}$. Atlantic MOC (e.g. HS-2 and HS-3, Lynch-Stieglitz et al., 2014) suggests that switches in atmospheric circulation rather than oceanic circulation played a crucial role in rapid basinscale transmission of these climate signals. Further improvements in high-resolution U-series dating of speleothems will require a more concerted inter-laboratory comparison exercise by the U-series dating community. Such improvements would allow better investigation of possible systematic changes with time in the magnitude of GI event offsets between NGRIP and the northern hemisphere speleothem records at the decadal level. Speculative drivers for possible latitudinal offsets in the timing of GI offsets include precession forcing, but these effects require further investigation to assess their robustness.

Oxygen isotope data of Last Glacial speleothems largely reflect changing oceanic source compositions linked to global ice volume. Kinetic isotope fractionation of oxygen and carbon isotope values in most of the last glacial speleothems precludes their use to reconstruct paleotemperatures. However, carbon isotope data provide useful insights into the impact of millennial-scale climate events during the last glacial at this mid-latitude terrestrial, but maritime setting. Low $\delta^{13} \mathrm{C}$ values indicate that biogenic $\mathrm{CO}_{2}$ production repeatedly commenced within a few decades after the onset of warming associated with stadialinterstadial transitions. This may reflect rapid re-establishments of local vegetation during interstadials, but the rapidity with which low $\delta^{13} \mathrm{C}$ values are established following each warming event points to a role for remobilisation of locally stored organic carbon, either in partly frozen soils or in the cave's epikarst.

\section{Acknowledgements}


$\mathrm{AF}$ and $\mathrm{FMcD}$ acknowledge financial support from Science Foundation Ireland (Grant 08/RFP/GEO1184). Dr Dirk Hoffmann is thanked for his help with the U-Th method and spike calibration. Prof. Stein-Erik Lauritzen kindly provided sample C58-2 and a standard sample for U-series dating. Mr Michael Murphy is thanked for his help in the UCD-NCIG isotope laboratory. The authors are grateful to two anonymous reviewers who provided constructive reviews that greatly improved our manuscript. The authors also thank the Geaney family at Crag cave for their permission to work at this site and for their kind hospitality during fieldwork over many years. 


\section{References}

Austin, W.E.N. and Hibbert, F.D. 2012. Tracing time in the ocean: a brief review of chronological constraints (60-8 kyr) on North Atlantic marine event-based stratigraphies. Quat. Sci. Rev. 36, 28-37.

Baker, A., Ito, E., Smart, P.L., McEwan, R.F., 1997. Elevated and variable values of ${ }^{13} \mathrm{C}$ in speleothems in a British cave system. Chem. Geol. 136, 263-270.

Ballantyne, C. K. \& Stone J. O. 2015. Trimlines, blockfields and the vertical extent of the last ice sheet in southern Ireland. Boreas, Vol. 44, pp. 277-287. 10.1111/bor.12109. ISSN 03009483.

Boch, R., Cheng, H., Spötl, C., Edwards, R.L., Wang, X., Häuselmann, Ph., 2011. NALPS: a precisely dated European climate record 120-60 ka. Clim. Past. 7, 1247-1259. http://dx.doi.org/10.5149/cp-7-1247-2011.

Bond, G., Broecker, W., Johnsen, S., McManus, J., Labeyrie, L., Jouzel, J., Bonani, G., 1993. Correalation between climate records from North Atlantic sediments and Greenland ice. Nature 365, 143-147.

Bowen, D.Q., Rose, J., McCabe, A.M., Sutherland, D.G. (1986) Correlation of Quaternary glaciations in England, Ireland, Scotland and Wales. Quat. Sci. Rev. 5, 299-340.

Buizert, C., Cuffey, K.M., Severinghaus, J.P., Baggenstos, D., Fudge, T.J., Steig, E.J., Markle, B.R., Winstrup, M., Rhodes, R.H., Brook, E.J., Sowers, T.A., Clow, G.D., Cheng, H., Edwards, R.L., Sigl, M., McConnell, J.R., Taylor K.C.The WAIS Divide deep ice core WD2014 chronology - Part 1: Methane synchronization (68-31 ka BP) and the gas age-ice age difference. Clim. Past 11, 2015, 153-173.

Burns, S.J., Fleitmann, D., Matter, A., Kramers, J., Abdulkarim, A. Al-Subbary 2003. Indian Ocean Climate and an Absolute Chronology over Dansgaard/Oeschger Events 9 to 13. Science 301, 1365-1367.

Cheng, H., Edwards, R.L., Shen, C.-C., Polyak, V.J., Asmerom, Y., Woodhead, J., Hellstrom, J., Wang, Y., Kong, X., Spötl, C., Wang, X., Calvin Alexander Jr., E., 2013. Improvements in ${ }^{230} \mathrm{Th}$ dating, ${ }^{230} \mathrm{Th}$ and ${ }^{234} \mathrm{U}$ half-life values, and U-Th isotopic measurements by multicollector inductively coupled plasma mass spectrometry. Earth Planet. Sci. Lett. 371-372, 8291.

Clark, P.U., Pisias, N.G., Stocker, T.F., Weaver, A.J., 2002. The role of the thermohaline circulation in abrupt climate change. Nature 415, 863-869.

Clark, C.D., Hughes, A.L.C., Greenwood, S.L., Jordan, C. and Sejrup, H.P. 2012. Pattern and timing of retreat of the last British-Orish Ice Sheet. Quat. Sci. Rev. 44, 112-146. 
Coope, G.R., Pennington, W., Mitchell, G. F., West, R. G., Morgan, A. V. and Peacock, J.D. 1977. Fossil coleopteran assemblages as sensitive indicators of climatic change during the Devensian (last) cold stage. Phil. Trans. R. Soc. Lond. B280, 313-340.

Colhoun, E.A., Dickson, J.H., McCabe, A.M. \& Shotton, F.W., 1972. A Middle Midlandian freshwater source at Derryvree, Maguiresbridge, County Fermanagh, Northern Ireland. R. Proc. R. Soc. Lond. B180, 273-282.

Dansgaard, W., Johnsen, S.J., Clausen, H.B., Dahl-Jensen, D., Gundestrup, N.S., Hammer, C.U., Hvidberg, C.S., Steffensen, J.P., Sveinbjörnsdottir, A.E., Jouzel, J., Bond G., 1993. Evidence for general instability of past climate from a 250-kyr ice-core record. Nature 364, 218-220.

Dreybrodt, W., and Deininger, M. 2014. The impact of evaporation to the isotope composition of DIC in calcite precipitating water films in equilibrium and kinetic fractionation models. Geochimica et Cosmochimica Acta 125, 433-439.

Dokken, T.M., Nisancioglu, K.H., Li, C., Battisti, D.S., Kissel, C., 2013. Dansgaard-Oeschger cycles: Interactions between ocean and sea ice intrinsic to the Northic seas. Paleoceanography 28, 491-502, doi:10.1002/palo.20042.

Elliot, M., Labeyrie, L., Duplessy, J.-C., 2002. Changes in North Atlantic deep-water formation associated with the Dansgaard-Oeschger temperature oscillation (60-10ka). Quat. Sci. Rev. 21, 1153-1165.

Eynaud, F., de Abreu, L., Voelker, A., Schönfeld, J., Salgueiro, E., Turon, J.-L., Penaud, A., Toucanne, S., Naughton, F., Sánchez Goñi, M.F., Malaizé, B., Cacho, I., 2009. Position of the Polar Front along the western Iberian margin during key cold episodes of the last $45 \mathrm{ka}$. Geochem. Geophys. Geosyst. 10, Q07U05, doi:10.1029/2009GC002398.

Fleitmann, D., Cheng, H., Badertscher, S., Edwards, R.L., Mudelsee, M., Göktürk, O.M., Fankhauser, A., Pickering, R., Raible, C.C., Matter, A., Kramers, J., Tüysüz, O., 2009. Timing and climatic impact of Greenland interstadials recorded in stalagmites from northern Turkey. Geophys. Res. Lett. 36, L19707. doi:10.1029/2009GL040050

Fletcher, W.J., Sánchez Goñi, M.F., Allen, J.M.R., Cheddadi, R., Combourieu-Nebout, N., Huntley, B., Lawson, I., Londeix, L., Magri, D., Margari, V., Müller, U.C., Naughton, F., Novenko, E., Roucoux, K., Tzedakis, P.C., 2010. Millennial-scale variability during the last glacial in vegetation records from Europe. Quat. Sci. Rev. 29, 2839-2864.

Frisia, S., 2015. Microstratigraphic logging of calcite fabrics in speleothems as tool for palaeoclimate studies. International Journal of Speleology 44, 1-16, Tampa FL (USA), ISSN 0392-6672 http://dx.doi.org/10.5038/1827-806X.44.1.1

Genty, D., Baker, A., Massault, M., Proctor, C., Gilmour, M., Pons-Branchu, E., Hamelin, B., 2001. Dead carbon in stalagmites: Carbonate bedrock paleodissolution vs. ageing of soil organic matter. Implications for ${ }^{13} \mathrm{C}$ variations in speleothems. Geochim. Cosmochim. Acta $65,3443-3457$. 
Genty, D., Blamart, D., Ouahdi, R., Gilmour, M., Baker, A., Jouzel, J, Van-Exter, S., 2003. Precise dating of Dansgaard-Oeschger climate oscillations in western Europe from stalagmite data. Nature 421, 833-837.

Genty, D., Combourieu-Nebout, N., Peyron, O., Blamart, D., Wainer, K., Mansuri, F., Ghaleb, B., Isabello, L., Dormoy, I., von Grafenstein, U., Bonelli, S., Landais, A., Brauer, A., 2010. Isotopic characterization of rapid climatic events during OIS3 and OIS4 in Villars Cave stalagmites (SW France) and correlation with Atlantic and Mediterranean pollen records. Quat. Sci. Rev. 29, 2799-2820.

Hall, I.R., Colmenero-Hidalgo, E., Zahn, R., V.L., Hemming, S.R., 2011. Centennial- to millennial-scale ice-ocean interactions in the subpolar northeast Atlantic 18-41 kyr ago. Paleoceanography 26, PA2224.

Hemming, S.R., 2004. Heinrich events: massive Late Pleistocene detritus layers of the North Atlantic and their global climate imprint. Rev. Geophys. 42, 1-43.

Hughes, A. L. C., Gyllencreutz, R., Lohne, Ø. S., Mangerud, J., Svendsen, J. I. 2016. The last Eurasian ice sheets - a chronological database and time-slice reconstruction, DATED-1. Boreas, Vol. 45, pp. 1-45. 10.1111/bor.12142. ISSN 0300-9483.

Jaffey, A.H., Flynn, K.F., Glendeni, L.E., Bentley, W.C. \& Essling, A.M., 1971. Precision measurement of half-lives and specific activities of ${ }^{235} U$ and ${ }^{238} U$. Phys. Rev. C4, 1889-1906.

Jiang, X., Wang, X., He, Y., Hu H.-M., Li, Z., Spötl, C., Shen, C.-C., 2016. Precisely dated multidecadally resolved Asian Summer Monsoon dynamics 113.5-86.6 thousand years ago. Quat. Sci. Rev. 143, 1-12.

Johnsen, S.J., Clausen, H.B., Dansgaard, W., Fuhrer, K., Gundestrup, N., Hammer, C.U., Iversen, P., Jouzel, J., Stauffer, B., Steffensen, J.P., 1992. Irregular glacial interstadials recorded in a new Greenland ice core. Nature 359, 311-313.

Johnsen, S.J., Dahl-Jensen, D., Gundestrup, N., Steffensen, J.P., Clausen, H.B., Miller, H., Masson-Delmotte, V., Sveinbjörnsdottir, A.E., White, J., 2001. Oxygen isotope and palaeotemperature records from six Greenland ice-core stations: Camp Century, Dye-3, GRIP, GISP2, Renland and NorthGRIP. J. of Quaternary Science 16, 299-307.

Johnston, V.E., 2010. The distribution and systematics of Cl-36 in meteoric waters and cave materials with an assessment of its use as a solar proxy in speleothems. Unpubl. PhD Thesis. University College Dublin, 315pp.

Kanner, L.C., Burns, S.J., Cheng, H., Edwards, R.L., 2012. High-latitude forcing of the South American summer monsoon during the last glacial. Science 335, 570-573. Doi: 10.1126/science. 1213397 .

Li, C., Battisti, D.S., Bitz, C.M., 2010. Can North Atlantic sea ice anomalies account for Dansgaard-Oeschger climate signals. American Meteorological Society, doi:10.1175/2010JCLI3409.1 
Luetscher, M., Boch, R., Sodemann, H., Spötl, C., Cheng, H., Edwards, R.L., Frisia, S., Hof, F., Müller, W., 2015. North Atlantic storm track changes during the Last Glacial Maximum recorded by Alpine speleothems. Nature Communications, doi: 10.1038/ncomms 7344.

Lynch-Stieglitz, J., Schmidt, M.W., Henry, L.G., Curry, W.B., Skinner, L.C., Mulitza, S., Zhang, R., Chang, P., 2014. Muted change in Atlantic overturning circulation over some glacial-aged Heinrich events. Nat. Geosci. 7, 144-150.

Margari, V., Skinner, L.C., Tzedakis, P.C., Ganopolski, A., Vautravers, M., Shackleton, N.J., 2010. The nature of millennial-scale climate variability during the past two glacial periods. Nat. Geosci. 3, 127-131, doi:10.1038/NGEO740.

McDermott, F., Frisia, S., Huang, Y., Longinelli, A., Spiro, B., Heaton, T.H.E., Hawkesworth, C.J., Borsato, A., Keppens, E., Fairchild, I.J., van der Borg, K., Verheyden, S., Selmo, E., 1999. Holocene climate variability in Europe: Evidence from $\delta^{18} \mathrm{O}$, textural and extension-rate variations in three speleothems. Quat. Sci. Rev. 18, 1021-1038.

McDermott, F., 2004. Palaeo-climate reconstructions from stable isotope variations in speleothems: a review. Quat. Sci. Rev. 23, 901-918.

McManus, J.F., Oppo, D.W., Cullen, J.L., 2001. ODP 980 Isotope and IRD Data, IGBP PAGES/World Data Centre A for Paleoclimatology Data Contribution Series \#2001-065. NOAA/NGDC Paleoclimatology Program, Boulder CO, USA.

Mook W. G., Bommerson J. C. and Staverman W. H. 1974. Carbon isotope fractionation between dissolved bicarbonate and gaseous carbon dioxide. Earth Planet Sci. Lett. 22, 169176.

Moseley G.E., Spötl C., Svensson A., Cheng H., Brandstätter S., Edwards R.L., 2014. Multispeleothem record reveals tightly coupled climate between central Europe and Greenland during Marine Isotope Stage 3. Geology 42, 1043-1046.

Moseley, G.E., Spötl, C., Cheng, H., Boch, R., Min, A., Edwards, R.L., 2015. Termination-II interstadial/stadial climate change recorded in two stalagmites from the north European Alps. Quat. Sci. Rev. 127, 229-239.

North Greenland Ice Core Project Members, 2004. High-resolution record of Northern Hemisphere climate extending into the last interglacial period. Nature 431, 147-151.

Peltier, W.R., Vettoretti, G., 2014. Dansgaard-Oeschger oscillations predicted in a comprehensive model of glacial climate: A "kicked" salt oscillator in the Atlantic. Geophys. Res. Lett. 41, 7306-7313, doi:10.1002/2014GL061413.

Pracht, M., 1996. Geology of Dingle Bay: a geological description to accompany the Bedrock Geology 1:100,000 Scale Map Series, Sheet 20, Dingle Bay. Geological Survey of Ireland. ISBN 1899702032 
Rachid, H., Hesse, R. \& Piper, D.J.W., 2003. Evidence for an additional Heinrich event between $\mathrm{H} 5$ and $\mathrm{H} 6$ in the Labrador Sea. Paleoceanography 18, 1077, doi:10.1029/2003PA000913.

Railsback, L.B., Liang. F., Vidal Romaní, J.R., Grandal-d'Anglade, A., Vaqueiro Rodríguez, M., Santos Fidalgo, L., Fernández Mosquera, D., Cheng, H., Edwards, R.L., 2011. Petrographic and isotopic evidence for Holocene long-term climate change and shorter-term environmental shifts from a stalagmite from the Serra do Courel of northwestern Spain, and implications for climatic history across Europe and the Mediterranean. Palaegeography, Palaeoclimatology, Palaeoecology 305, 172-184.

Rasmussen, S.O., Bigler, M., Blockley, S.P., Blunier, T., Buchardt, S.L., Clausen, H.B., Cvijanovic, I., Dahl-Jensen, D., Johnsen, S.J., Fischer, H., Gkinis, V., Guillevic, M., Hoek, W.Z., Lowe, J.J., Pedro, J.B., Popp, T., Seierstad, I.K., Steffensen, J.P., Svensson, A.M., Vallelonga, P., Vinther, B.M. Walker, M.J.C., Wheatley, J.J., Winstrup, M., 2014. A stratigraphic framework for abrupt climatic changes during the Last Glacial period based on three synchronized Greenland ice-core records: refining and extending the INTIMATE event stratigraphy. Quat. Sci. Rev. 106, 14-28.

Richards, D.A., Dorale, J.A., 2003. Uranium-series chronology and environmental applications of speleothems, in: Bourdon, B., Henderson, G.M., Lundstrom, C.C., Turner, S.P. (Eds.), Uranium-series geochemistry. Rev. Mineralogy and Geochemistry 52, 407-460.

Rudzka, D., McDermott, F., Baldini, L.M., Fleitmann, D., Moreno, A., Stoll, H., 2011. The coupled $\delta^{13} \mathrm{C}$-radiocarbon systematics of three Late Glacial/early Holocene speleothems; insights into soil and cave processes at climatic transitions. Geochim. Cosmochim. Acta 75, 4321-4339.

Salgueiro, E., Voelker, A.H.L., de Abreu, L., Abrantes, F., Meggers, H., Wefer, G., 2010. Temperature and productivity changes off the western Iberian margin during the last 150 ky. Quat. Sci. Rev. 29, 680-695.

Salomons, W. and Mook, W.G. 1986. Isotope geochemistry of carbonates in the weathering zone, In Handbook of Environmental Isotope Geochemistry Vol. 2 The Terrestrial Environment (eds. P. Fritz and C.J. Fontes), Elsevier, Amsterdam, pp. 239-270.

Sánchez Goñi, M.F., Landais, A., Fletcher, W.J., Naughton, F., Desprat, S., Duprat, J., 2008. Contrasting impacts of Dansgaard-Oeschger events over western European latitudinal transect modulated by orbital parameters. Quat. Sci. Rev. 27, 1136-1151.

Sánchez Goñi, M.F., Harrison, S.P., 2010. Millennial-scale climate variability and vegetation changes during the Last Glacial: Concepts and terminology. Quat. Sci. Rev. 29, 2825-2827.

Spötl, C., Mangini, A., Richards, D., 2006. Chronology and paleoenvironment of Marine Isotope Stage 3 from two high-elevation speleothems, Austrian Alps. Quat. Sci. Rev. 25, 1127-1136.

Stocker, T.F., 1998. The Seesaw effect. Science 282, 61-62. 
Stoll, H.M., Moreno, A., Mendez-Vicente, A., Gonzalez-Lemos, S., Jimenez-Sanchez, M., Dominguez-Cuesta, M.J., Edwards, R.L., Cheng, H., Wang, X., 2013. Paleoclimate and growth rates of speleothems in the northwestern Iberian Peninsula over the last two glacial cycles. Quat. Res. 80, 284-290.

Svensson, A., Andersen, K.K., Bigler, M., Clausen, H.B., Dahl-Jensen, D., Davies, S.M., Johnsen, S.J., Muscheler, R., Parrenin, F., Rasmussen, S.O., Röthlisberger, R., Seierstad, I., Steffensen, J.P., Vinther, B.M., 2008. A 60000 year Greenland stratigraphic ice core chronology. Clim. Past. 4, 47-57.

Tooth, A.F., Fairchild, I.J., 2003. Soil and karst aquifer hydrological controls on the geochemical evolution of speleothem-forming drip waters, Crag Cave, southwest Ireland. Journal of Hydrology 237, 51-68.

van Kreveld, S., Sarnthein, M., Erlenkeuser, H., Grootes, P., Jung, S., Nadeau, M.J., Pflaumann, U., Voelker, A., 2000. Potential links between surging ice sheets, circulation changes, and the Dansgaard-Oeschger cycles in the Irminger Sea, 60-18 kyr. Paleoceanography 15, 425-442.

van Ommen, T., 2015. Northern push for the bipolar see-saw. Nature 520, 630-631.

Voelker, A.H.L., Workshop Participants, 2002. Global distribution of centennial-scale records for Marine Isotope Stage (MIS) 3: a database. Quat. Sci. Rev. 21, 1185-1212.

WAIS Divide Project Members, 2015. Precise interpolar phasing of abrupt climate change during the last ice age. Nature 520, 661-665. doi:10.1038/nature14401

Wainer, K., Genty, D., Blamart, D., Hoffmann, D., Couchoud I., 2009. A new stage 3 millennial climatic variability record from a SW France speleothem. Palaegeography, Palaeoclimatology, Palaeoecology 271, 130-139.

Wang Y.J., Cheng H., Edwards R.L., An Z.S., Wu J.Y., Shen C.-C., Dorale J.A., 2001. A high-resolution absolute-dated Late Pleistocene Monsoon record from Hulu Cave, China. Science 294, 2345-2348.

Wohlfarth, B., Veres, D., Ampel, L., Lacourse, T., Blaauw, M., Preusser, F., Andrieu-Ponel, V., Kéravis, D., Lailler-Vergès, E.,Björck, S., Davies, S.M., de Beaulieu, J.-L., Risberg, J., Hormes, A., Kasper, H.U., Possnert, G., Reille, M., Thouveny, N., Zander, A., 2008. Rapid ecosystem response to abrupt climate changes during the last glacial period in western Europe, 40-16 ka. Geology 36, 407-410. doi: 10.1130/G24600A.1

Woodman P., McCarthy M., Monaghan N., 1997. The Irish Quaternary fauna project. Quat. Sci. Rev. 16, 129-159.

Wolff, E.W., Chappellaz J., Blunier T., Rasmussen S.O., Svensson A., 2010. Millennial-scale variability during the Last Glacial: The ice core record. Quat. Sci. Rev. 29, 2828-2838. 
Wynn, P.M., Fairchild, I.J., Baker, A., Baldini, J.U.L., McDermott, F., 2008. Isotopic archives of sulphate in speleothems. Geochimica et Cosmochimica Acta 72, 2465-2477.

Zhao, K., Wang, Y., Edwards R.L., Cheng H., Liu, D., 2010. High-resolution stalagmite $\delta^{18} \mathrm{O}$ records of Asian monsoon changes in central and southern China spanning the MIS 3/2 transition. Earth Planet. Sci. Letts. 298, 191-198.

Zhou, H., Zhao, J., Feng, Y., Gagan, M.K., Zhou, G., Yan, J., 2008. Distinct climate change synchronous with Heinrich event one, recorded by stable oxygen and carbon isotopic compositions in stalagmites from China. Quat. Res. 69, 306-315. 
Table and Figure Captions

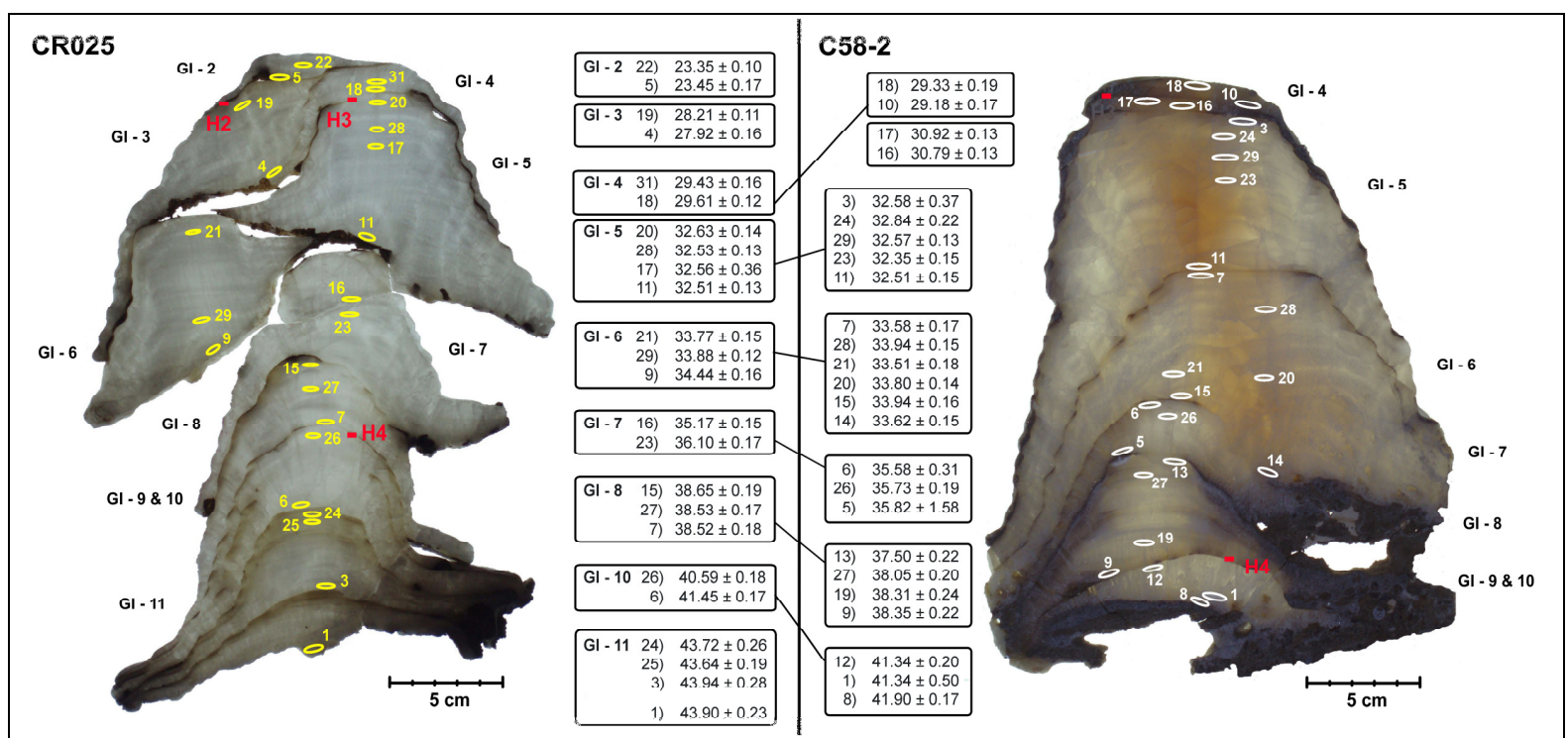

Fig. 1: Photographs showing cross-sections through the two key stalagmites CR025 and C582 with positions of samples for U-series dating (yellow and white ellipses) and U-series dates (ka). Depositional phases that can be correlated with Greenland Interstadials in the two stalagmites are labelled. $\mathrm{H} 2, \mathrm{H} 3$ and $\mathrm{H} 4$ in red pinpoint the non-deposition intervals which can be correlated to Heinrich stadials. 


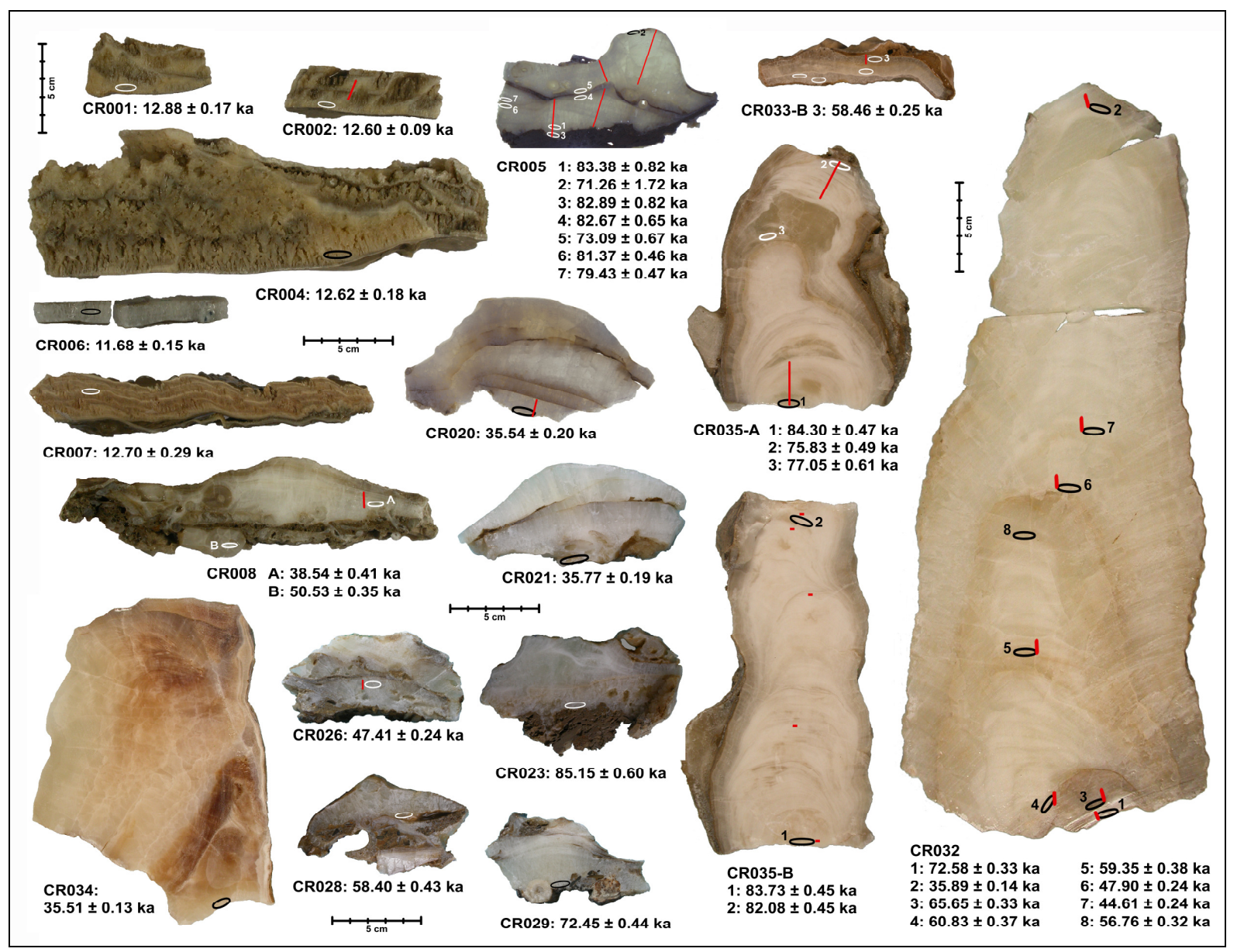

Fig. 2: Picture showing the range of last glacial Crag cave speleothems that have been Useries dated in this study, illustrating that depositional pulses and hiatuses are not restricted to a small number of samples. The sampling points for U-series dating (black or white) and the tracks for stable isotope analyses (red) are also indicated. 


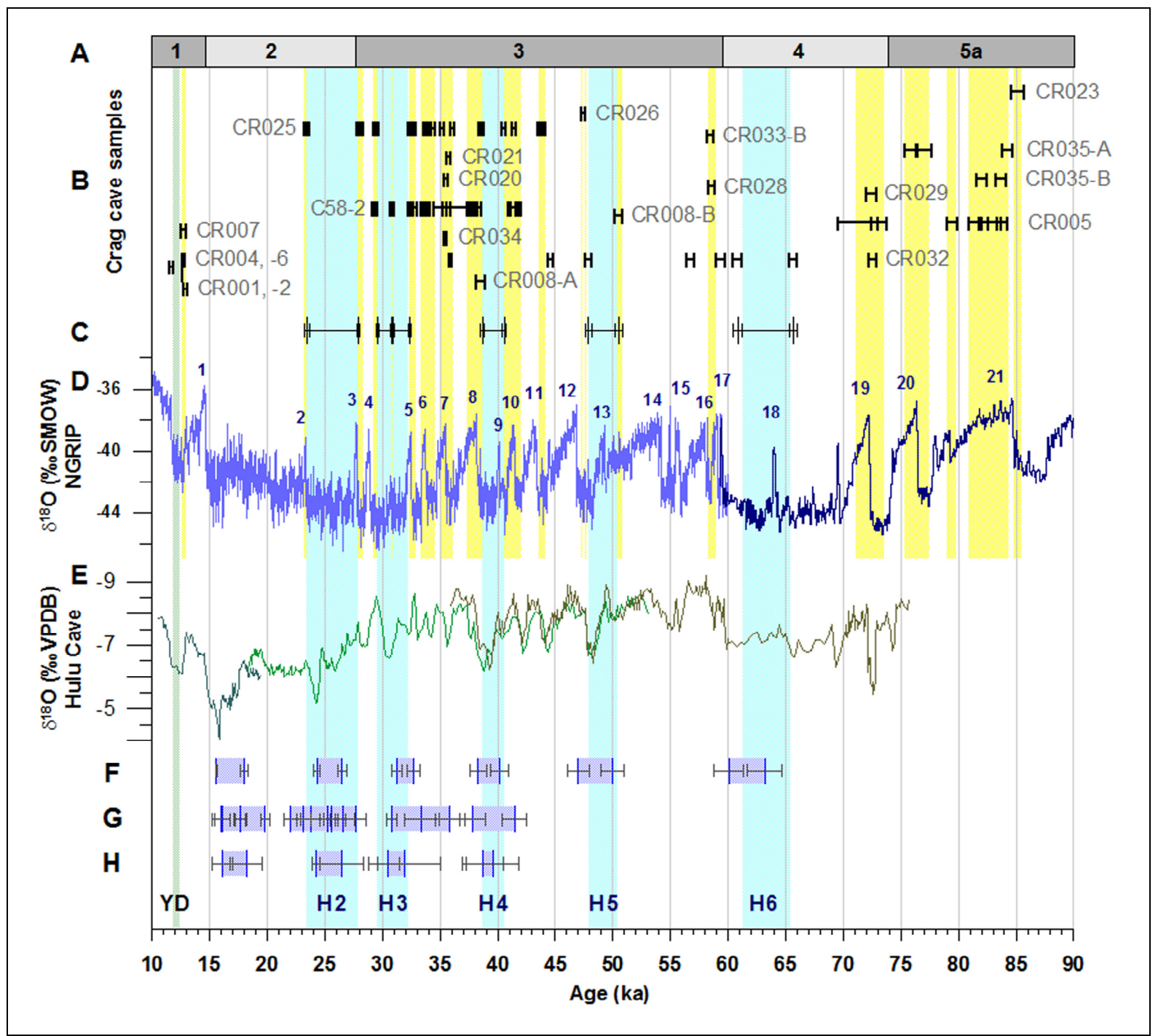

Fig. 3: (A) The timing of Marine Isotope Stages (MIS5a to 1) (Sánchez Goñi and Harrison, 2010) is shown, adjusted to NGRIP (Svensson et al., 2008; Wolff et al., 2010). (B) Black data points with $2 \sigma$ error bars show the new U-series ages for last glacial speleothems from Crag cave. Yellow (deposition) and blue (non-deposition) vertical bars are inferred to be the expression of GI and Heinrich stadials respectively in the Crag cave dataset. (C) Intervals of non-deposition in Crag cave dataset interpreted to reflect Heinrich stadials H5 to H2. (D) NGRIP $\delta^{18} \mathrm{O}$ curve (North Greenland Ice Core Project Members, 2004) (blue) and its chronology (orange bars and $1 \sigma$ errors of show the onset of GI events) after references (Svensson et al., 2008; Wolff et al., 2010). (E) $\delta^{18}$ O speleothem record from Hulu cave China (Wang et al., 2001). Blue shaded boxes in the lower part of the diagram indicate the timing of Heinrich stadials after Sánchez Goñi and Harrison (2010) (F); Bond et al. (1993) (G); Elliot et al. (2002) (H). 


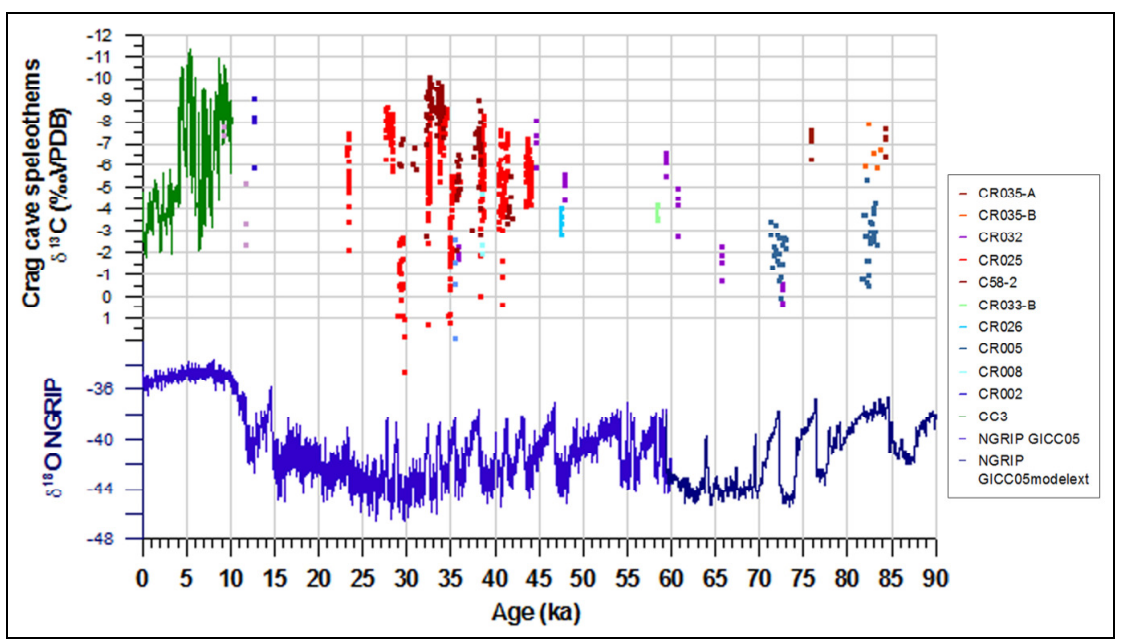

Fig. 4: $\delta^{13} \mathrm{C}$ values for the analysed Crag cave last glacial speleothems, compared with a published data for a Holocene stalagmite (CC3) from this cave (McDermott et al., 1999). The NGRIP $\delta^{18} \mathrm{O}$ record (North Greenland Ice Core Project Members, 2004; Svensson et al., 2008; Wolff et al., 2010, Rasmussen et al., 2014) is also shown for reference. Note that $\delta^{13} \mathrm{C}$ and $\delta^{18} \mathrm{O}$ are strongly correlated within most of the last glacial samples (Fig. 6) indicating that only the sub-samples that display the lowest $\delta^{13} \mathrm{C}$ values are likely to reflect temporal changes in climate-driven biogenic $\mathrm{CO}_{2}$ production.

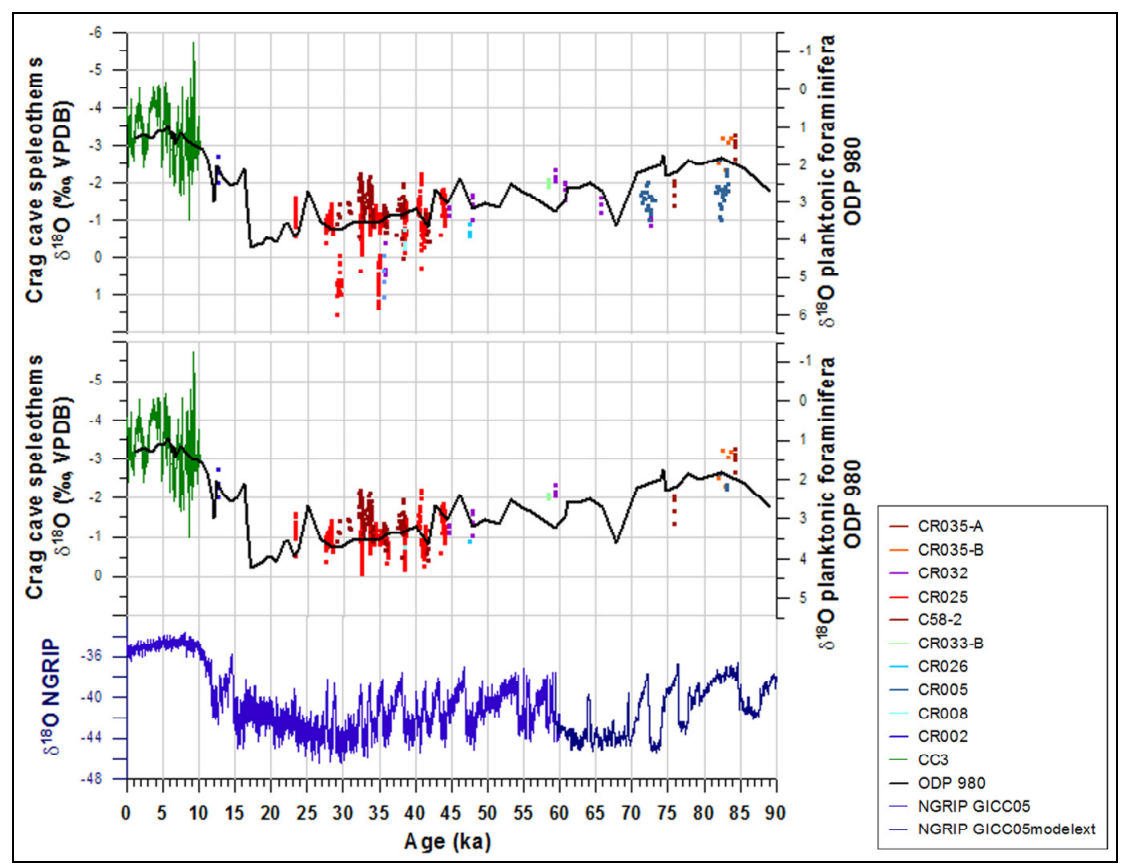

Fig. 5: (A) $\delta^{18} \mathrm{O}$ measured in a range of last glacial speleothems from Crag cave The upper panel shows all of the data and the middle panel shown the $\delta^{18} \mathrm{O}$ data for those samples for which $\delta^{13} \mathrm{C}$ is $<-4.0 \%$ o to eliminate those affected strongly by kinetic isotope fractionation effects. Also shown (black line) is the curve for planktonic foraminifera $\delta^{18} \mathrm{O}$ from the $\mathrm{N}$. Atlantic core ODP 980 (McManus et al., 2001) and the NGRIP $\delta^{18} \mathrm{O}$ record. Note that $\delta^{13} \mathrm{C}$ and $\delta^{18} \mathrm{O}$ are strongly correlated within most of the last glacial samples (Fig. 6) indicating that only the sub-samples that display the lowest $\delta^{18} \mathrm{O}$ values are likely to reflect temporal changes in climate-driven $\delta^{18} \mathrm{O}$. 


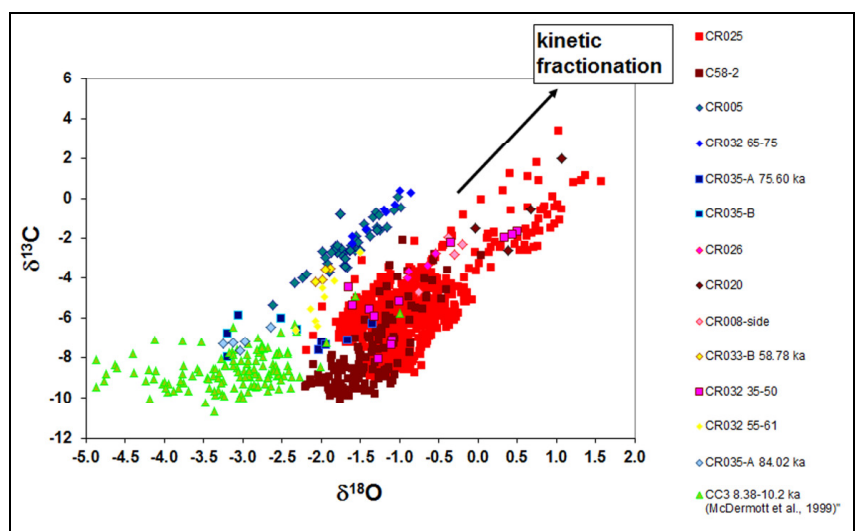

Fig. 6: $\delta^{18} \mathrm{O}$ vs. $\delta^{13} \mathrm{C}$ data for all of the analysed Crag cave LG speleothems, compared with a previously published dataset for a Holocene stalagmite (CC3) from this cave (McDermott et al., 1999). The strong correlation between $\delta^{18} \mathrm{O}$ and $\delta^{13} \mathrm{C}$ is indicative of kinetic isotope enrichment effects (Dreybrodt and Deininger, 2014).

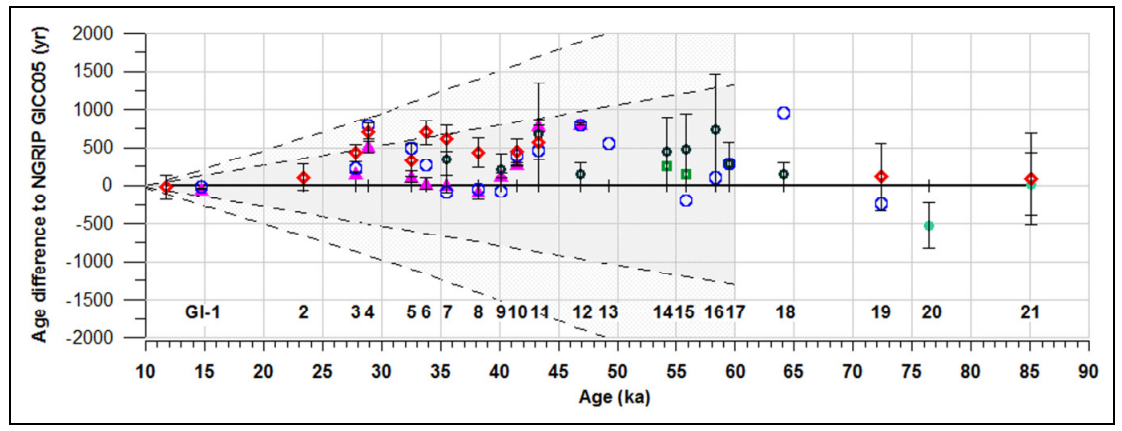

Fig. 7: Data points depict the difference in timing of GI events identified in speleothem records from several caves, plotted against their NGRIP chronology (Svensson et al., 2008; Wolff et al., 2010). Data are from Crag cave (red diamonds), Hulu Cave (China) (Wang et al., 2001) (blue circles), Sofular Cave (Turkey) (Fleitmann et al., 2009) (pink triangles), Kleegruben cave (Spötl et al., 2006) (green squares) and the NALPS record (light green circles (Boch et al., 2011) and dark green circles (Moseley et al., 2014)). For NGRIP, the GICC05 chronology (Svensson et al., 2008) was used until 60ka, and the GICC05modelext chronology, the original chronology modified after Wolff et al., (2010) was used for the ages $>60 \mathrm{ka}$. The inner shaded triangle represents the $1 \sigma$ uncertainty, the outer dashed line $2 \sigma$, on the NGRIP chronology (Svensson et al., 2008; Wolff et al., 2010, Rasmussen et al., 2014). 


\begin{tabular}{|c|c|c|c|c|c|c|c|}
\hline Sample name & ${ }^{238} \mathrm{U}$ (ppm) & $\left({ }^{230} \mathrm{Th} /{ }^{238} \mathrm{U}\right)_{\mathrm{m}}$ & $\left({ }^{234} \mathrm{U} /{ }^{238} \mathrm{U}\right)_{\mathrm{m}}$ & $\left({ }^{234} \mathrm{U} /{ }^{238} \mathrm{U}\right)_{\text {inital }}$ & $\left({ }^{230} \mathrm{Th} /{ }^{232} \mathrm{Th}\right)$ & Age uncorrected (ka) & Age detrital correcte \\
\hline C58-2 U-Th-1 & $4.697 \pm 0.005$ & $0.3061 \pm 0.0011$ & $0.9707 \pm 0.0065$ & $0.9671 \pm 0.0124$ & $681.2 \pm 2.1$ & $41.40 \pm 0.47$ & $41.34 \pm 0.50$ \\
\hline C58-2 U-Th-3 & $2.667 \pm 0.004$ & $0.2558 \pm 0.0013$ & $0.9892 \pm 0.0048$ & $0.9882 \pm 0.0118$ & $521.1 \pm 2.6$ & $32.64 \pm 0.34$ & $32.58 \pm 0.37$ \\
\hline C58-2 UTh-5 & $2.527 \pm 0.004$ & $0.2759 \pm 0.0091$ & $0.9818 \pm 0.0026$ & $0.9799 \pm 0.0439$ & $175.9 \pm 3.6$ & $36.01 \pm 1.49$ & $35.82 \pm 1.58$ \\
\hline C58-2 U-Th-6 & $1.745 \pm 0.003$ & $0.2740 \pm 0.0015$ & $0.9846 \pm 0.0026$ & $0.9829 \pm 0.0092$ & $3364.9 \pm 17.1$ & $35.59 \pm 0.30$ & $35.58 \pm 0.31$ \\
\hline C58-2 U-Th-7 & $2.992 \pm 0.005$ & $0.2664 \pm 0.0008$ & $1.0047 \pm 0.0024$ & $1.0052 \pm 0.0059$ & $2045.6 \pm 5.5$ & $33.59 \pm 0.17$ & $33.58 \pm 0.17$ \\
\hline C58-2 U-Th-8 & $5.473 \pm 0.006$ & $0.3083 \pm 0.0005$ & $0.9673 \pm 0.0024$ & $0.9631 \pm 0.0046$ & $917.3 \pm 2.0$ & $41.95 \pm 0.15$ & $41.90 \pm 0.17$ \\
\hline C58-2 U-Th-9 & $4.736 \pm 0.005$ & $0.2976 \pm 0.0006$ & $1.0017 \pm 0.0025$ & $1.0019 \pm 0.0064$ & $378.9 \pm 1.0$ & $38.44 \pm 0.16$ & $38.35 \pm 0.22$ \\
\hline C58-2 U-Th-10 & $4.310 \pm 0.004$ & $0.2419 \pm 0.0005$ & $1.0260 \pm 0.0025$ & $1.0282 \pm 0.0069$ & $267.9 \pm 0.7$ & $29.28 \pm 0.11$ & $29.18 \pm 0.17$ \\
\hline C58-2 U-Th-11 & $4.931 \pm 0.005$ & $0.2582 \pm 0.0006$ & $1.0015 \pm 0.0024$ & $1.0017 \pm 0.0053$ & $4457.8 \pm 13.3$ & $32.52 \pm 0.14$ & $32.51 \pm 0.15$ \\
\hline C58-2 U-Th-12 & $1.776 \pm 0.002$ & $0.3066 \pm 0.0007$ & $0.9726 \pm 0.0024$ & $0.9692 \pm 0.0053$ & $1350.7 \pm 4.1$ & $41.37 \pm 0.18$ & $41.34 \pm 0.20$ \\
\hline C58-2 U-Th-13 & $1.993 \pm 0.003$ & $0.2870 \pm 0.0008$ & $0.9853 \pm 0.0025$ & $0.9836 \pm 0.0065$ & $520.9 \pm 1.8$ & $37.57 \pm 0.18$ & $37.50 \pm 0.22$ \\
\hline C58-2 U-Th-14 & $5.669 \pm 0.008$ & $0.2636 \pm 0.0005$ & $0.9930 \pm 0.0025$ & $0.9923 \pm 0.0053$ & $766.2 \pm 2.1$ & $33.66 \pm 0.13$ & $33.62 \pm 0.15$ \\
\hline C58-2 U-Th-15 & $2.928 \pm 0.005$ & $0.2664 \pm 0.0007$ & $0.9957 \pm 0.0025$ & $0.9953 \pm 0.0055$ & $1533.4 \pm 4.9$ & $33.97 \pm 0.15$ & $33.94 \pm 0.16$ \\
\hline C58-2 U-Th-16 & $4.830 \pm 0.007$ & $0.2498 \pm 0.0005$ & $1.0137 \pm 0.0025$ & $1.0149 \pm 0.0052$ & $844.8 \pm 2.3$ & $30.83 \pm 0.12$ & $30.79 \pm 0.13$ \\
\hline C58-2 U-Th-17 & $4.955 \pm 0.008$ & $0.2496 \pm 0.0005$ & $1.0102 \pm 0.0025$ & $1.0112 \pm 0.0050$ & $2337.8 \pm 7.0$ & $30.94 \pm 0.12$ & $30.92 \pm 0.13$ \\
\hline C58-2 U-Th-18 & $3.024 \pm 0.004$ & $0.2405 \pm 0.0006$ & $1.0162 \pm 0.0025$ & $1.0176 \pm 0.0073$ & $267.9 \pm 0.8$ & $29.43 \pm 0.12$ & $29.33 \pm 0.19$ \\
\hline C58-2 U-Th-19 & $0.996 \pm 0.002$ & $0.2932 \pm 0.0008$ & $0.9884 \pm 0.0025$ & $0.9871 \pm 0.0069$ & $439.6 \pm 1.7$ & $38.40 \pm 0.19$ & $38.31 \pm 0.24$ \\
\hline C58-2 U-Th-20 & $2.934 \pm 0.005$ & $0.2672 \pm 0.0006$ & $1.0021 \pm 0.0025$ & $1.0023 \pm 0.0049$ & $3274.4 \pm 11.7$ & $33.81 \pm 0.14$ & $33.80 \pm 0.14$ \\
\hline C58-2 U-Th-21 & $2.170 \pm 0.003$ & $0.2654 \pm 0.0008$ & $1.0026 \pm 0.0025$ & $1.0029 \pm 0.0062$ & $2112.1 \pm 8.8$ & $33.52 \pm 0.18$ & $33.51 \pm 0.18$ \\
\hline C58-2 U-Th-23 & $2.720 \pm 0.004$ & $0.2576 \pm 0.0007$ & $1.0032 \pm 0.0024$ & $1.0036 \pm 0.0054$ & $5177.6 \pm 24.8$ & $32.36 \pm 0.15$ & $32.35 \pm 0.15$ \\
\hline C58-2_UTh-24 & $2.419 \pm 0.004$ & $0.2584 \pm 0.0011$ & $0.9938 \pm 0.0025$ & $0.9932 \pm 0.0073$ & $2766.4 \pm 10.2$ & $32.85 \pm 0.21$ & $32.84 \pm 0.22$ \\
\hline C58-2 U-Th-26 & $2.209 \pm 0.003$ & $0.2764 \pm 0.0007$ & $0.9890 \pm 0.0024$ & $0.9878 \pm 0.0059$ & $1091.1 \pm 3.6$ & $35.76 \pm 0.17$ & $35.73 \pm 0.19$ \\
\hline C58-2 U-Th-27 & $2.084 \pm 0.003$ & $0.2882 \pm 0.0007$ & $0.9788 \pm 0.0024$ & $0.9764 \pm 0.0057$ & $1176.2 \pm 3.6$ & $38.08 \pm 0.18$ & $38.05 \pm 0.20$ \\
\hline C58-2 U-Th-28 & $2.849 \pm 0.004$ & $0.2657 \pm 0.0006$ & $0.9934 \pm 0.0026$ & $0.9928 \pm 0.0050$ & $3167.4 \pm 9.2$ & $33.95 \pm 0.14$ & $33.94 \pm 0.15$ \\
\hline C58-2 U-Th-29 & $2.728 \pm 0.004$ & $0.2566 \pm 0.0005$ & $0.9939 \pm 0.0025$ & $0.9933 \pm 0.0046$ & $4853.4 \pm 17.4$ & $32.58 \pm 0.12$ & $32.57 \pm 0.13$ \\
\hline CR025 U-Th-1 & $4.830 \pm 0.007$ & $0.3309 \pm 0.0008$ & $0.9982 \pm 0.0025$ & $0.9980 \pm 0.0058$ & $2128.5 \pm 5.2$ & $43.93 \pm 0.22$ & $43.90 \pm 0.23$ \\
\hline CR025 U-Th-3 & $4.554 \pm 0.006$ & $0.3270 \pm 0.0012$ & $0.9866 \pm 0.0026$ & $0.9848 \pm 0.0069$ & $5079.4 \pm 17.4$ & $43.94 \pm 0.28$ & $43.94 \pm 0.28$ \\
\hline CR025 U-Th-4 & $10.106 \pm 0.012$ & $0.2481 \pm 0.0009$ & $1.0948 \pm 0.0026$ & $1.1025 \pm 0.0070$ & $8478.0 \pm 22.1$ & $27.92 \pm 0.15$ & $27.92 \pm 0.16$ \\
\hline CR025 U-Th-5 & $18.259 \pm 0.021$ & $0.2255 \pm 0.0012$ & $1.1604 \pm 0.0028$ & $1.1714 \pm 0.0095$ & $7375.5 \pm 18.9$ & $23.45 \pm 0.17$ & $23.45 \pm 0.17$ \\
\hline CR025 U-Th-6 & $10.386 \pm 0.017$ & $0.3179 \pm 0.0006$ & $1.0049 \pm 0.0025$ & $1.0055 \pm 0.0048$ & $12693.3 \pm 41.6$ & $41.46 \pm 0.17$ & $41.45 \pm 0.17$ \\
\hline CR025 U-Th-7 & $6.201 \pm 0.010$ & $0.3097 \pm 0.0008$ & $1.0384 \pm 0.0025$ & $1.0428 \pm 0.0056$ & $7570.1 \pm 28.1$ & $38.53 \pm 0.18$ & $38.52 \pm 0.18$ \\
\hline CR025 U-Th-9 & $8.524 \pm 0.016$ & $0.2816 \pm 0.0007$ & $1.0380 \pm 0.0025$ & $1.0419 \pm 0.0055$ & $18112.6 \pm 110.8$ & $34.44 \pm 0.16$ & $34.44 \pm 0.16$ \\
\hline CR025 U-Th-11 & $7.328 \pm 0.010$ & $0.2700 \pm 0.0006$ & $1.0453 \pm 0.0025$ & $1.0497 \pm 0.0049$ & $4217.7 \pm 10.9$ & $32.51 \pm 0.13$ & $32.51 \pm 0.13$ \\
\hline CR025 U-Th-15 & $4.134 \pm 0.007$ & $0.3036 \pm 0.0008$ & $1.0162 \pm 0.0026$ & $1.0180 \pm 0.0057$ & $17822.0 \pm 149.6$ & $38.66 \pm 0.19$ & $38.65 \pm 0.19$ \\
\hline CR025 U-Th-16 & $5.820 \pm 0.010$ & $0.2800 \pm 0.0006$ & $1.0149 \pm 0.0025$ & $1.0165 \pm 0.0051$ & $6500.6 \pm 22.1$ & $35.17 \pm 0.15$ & $35.17 \pm 0.15$ \\
\hline CR025 U-Th-17 & $4.945 \pm 0.010$ & $0.2674 \pm 0.0022$ & $1.0343 \pm 0.0025$ & $1.0376 \pm 0.0124$ & $9004.8 \pm 830.6$ & $32.56 \pm 0.36$ & $32.56 \pm 0.36$ \\
\hline CR025 U-Th-18 & $7.540 \pm 0.012$ & $0.2556 \pm 0.0005$ & $1.0717 \pm 0.0027$ & $1.0780 \pm 0.0050$ & $6779.9 \pm 21.7$ & $29.61 \pm 0.11$ & $29.61 \pm 0.12$ \\
\hline CR025 U-Th-19 & $6.703 \pm 0.011$ & $0.2415 \pm 0.0005$ & $1.0570 \pm 0.0026$ & $1.0617 \pm 0.0050$ & $4739.1 \pm 13.9$ & $28.21 \pm 0.11$ & $28.21 \pm 0.11$ \\
\hline CR025 U-Th-20 & $5.264 \pm 0.008$ & $0.2646 \pm 0.0006$ & $1.0219 \pm 0.0025$ & $1.0241 \pm 0.0052$ & $6253.5 \pm 24.2$ & $32.64 \pm 0.14$ & $32.63 \pm 0.14$ \\
\hline CR025 U-Th-21 & $5.014 \pm 0.008$ & $0.2715 \pm 0.0007$ & $1.0184 \pm 0.0025$ & $1.0203 \pm 0.0054$ & $9139.6 \pm 45.6$ & $33.77 \pm 0.15$ & $33.77 \pm 0.15$ \\
\hline CR025 U-Th-22 & $18.802 \pm 0.028$ & $0.2206 \pm 0.0005$ & $1.1397 \pm 0.0029$ & $1.1492 \pm 0.0056$ & $21991.0 \pm 84.0$ & $23.35 \pm 0.10$ & $23.35 \pm 0.10$ \\
\hline CR025 U-Th-23 & $4.047 \pm 0.006$ & $0.2858 \pm 0.0007$ & $1.0133 \pm 0.0027$ & $1.0147 \pm 0.0055$ & $8559.7 \pm 40.7$ & $36.10 \pm 0.17$ & $36.10 \pm 0.17$ \\
\hline CR025 U-Th-24 & $5.049 \pm 0.008$ & $0.3284 \pm 0.0009$ & $0.9935 \pm 0.0025$ & $0.9927 \pm 0.0064$ & $752.9 \pm 2.4$ & $43.78 \pm 0.23$ & $43.72 \pm 0.26$ \\
\hline CR025 U-Th-25 & $4.631 \pm 0.006$ & $0.3255 \pm 0.0005$ & $0.9869 \pm 0.0026$ & $0.9851 \pm 0.0049$ & $1214.9 \pm 2.8$ & $43.68 \pm 0.17$ & $43.64 \pm 0.19$ \\
\hline CR025 U-Th-26 & $6.594 \pm 0.011$ & $0.3107 \pm 0.0007$ & $0.9997 \pm 0.0025$ & $0.9997 \pm 0.0050$ & $23241.8 \pm 109.3$ & $40.59 \pm 0.18$ & $40.59 \pm 0.18$ \\
\hline CR025 U-Th-27 & $4.921 \pm 0.007$ & $0.3034 \pm 0.0007$ & $1.0182 \pm 0.0026$ & $1.0203 \pm 0.0051$ & $33242.4 \pm 245.0$ & $38.53 \pm 0.17$ & $38.53 \pm 0.17$ \\
\hline CR025 U-Th-28 & $7.227 \pm 0.014$ & $0.2644 \pm 0.0005$ & $1.0242 \pm 0.0026$ & $1.0265 \pm 0.0047$ & $14052.8 \pm 51.4$ & $32.53 \pm 0.13$ & $32.53 \pm 0.13$ \\
\hline CR025 U-Th-29 & $6.343 \pm 0.009$ & $0.2733 \pm 0.0005$ & $1.0223 \pm 0.0026$ & $1.0245 \pm 0.0045$ & $22483.2 \pm 104.5$ & $33.89 \pm 0.12$ & $33.88 \pm 0.12$ \\
\hline CR025 U-Th-31 & $6.143 \pm 0.009$ & $0.2524 \pm 0.0009$ & $1.0644 \pm 0.0027$ & $1.0700 \pm 0.0068$ & $5200.1 \pm 14.2$ & $29.43 \pm 0.16$ & $29.43 \pm 0.16$ \\
\hline CR001 U-Th-1 & $4.940 \pm 0.005$ & $0.1140 \pm 0.0002$ & $1.0113 \pm 0.0025$ & $1.0117 \pm 0.0143$ & 0.2 & $13.04 \pm 0.04$ & $12.88 \pm 0.17$ \\
\hline CR002 U-Th-1 & $4.595 \pm 0.005$ & $0.1111 \pm 0.0002$ & $1.0130 \pm 0.0025$ & $1.0134 \pm 0.0085$ & $150.0 \pm 0.4$ & $12.67 \pm 0.04$ & $12.60 \pm 0.09$ \\
\hline CR004 U-Th-1 & $6.048 \pm 0.012$ & $0.1111 \pm 0.0005$ & $1.0088 \pm 0.0056$ & $1.0091 \pm 0.0152$ & $106.6 \pm 0.4$ & $12.72 \pm 0.11$ & $12.62 \pm 0.18$ \\
\hline CR005 U-Th-1 & $17.384 \pm 0.024$ & $0.5040 \pm 0.0016$ & $0.9486 \pm 0.0036$ & $0.9349 \pm 0.0093$ & $6100.1 \pm 14.8$ & $83.40 \pm 0.81$ & $83.38 \pm 0.82$ \\
\hline CR005 U-Th-2 & $23.399 \pm 0.053$ & $0.4580 \pm 0.0057$ & $0.9585 \pm 0.0049$ & $0.9492 \pm 0.0231$ & $18268.3 \pm 134.8$ & $71.27 \pm 1.72$ & $71.26 \pm 1.72$ \\
\hline CR005 U-Th-3 & $31.007 \pm 0.053$ & $0.5145 \pm 0.0025$ & $0.9697 \pm 0.0024$ & $0.9617 \pm 0.0095$ & $43805.6 \pm 180.1$ & $82.90 \pm 0.81$ & $82.89 \pm 0.82$ \\
\hline CR005 U-Th-4 & $7.319 \pm 0.013$ & $0.4969 \pm 0.0016$ & $0.9412 \pm 0.0023$ & $0.9257 \pm 0.0073$ & $2154.9 \pm 5.1$ & $82.72 \pm 0.63$ & $82.67 \pm 0.65$ \\
\hline CR005 U-Th-5 & $18.193 \pm 0.032$ & $0.4731 \pm 0.0022$ & $0.9714 \pm 0.0025$ & $0.9649 \pm 0.0090$ & $31611.2 \pm 105.1$ & $73.09 \pm 0.67$ & $73.09 \pm 0.67$ \\
\hline CR005 U-Th-6 & $13.404 \pm 19.627$ & $0.5061 \pm 0.0010$ & $0.9660 \pm 0.0024$ & $0.9572 \pm 0.0054$ & $12390.9 \pm 30.7$ & $81.38 \pm 0.45$ & $81.37 \pm 0.46$ \\
\hline CR005 U-Th-7 & $7.807 \pm 10.505$ & $0.4876 \pm 0.0011$ & $0.9479 \pm 0.0023$ & $0.9348 \pm 0.0056$ & $8809.6 \pm 26.9$ & $79.44 \pm 0.46$ & $79.43 \pm 0.47$ \\
\hline CR006 U-Th-1 & $4.063 \pm 0.010$ & $0.0982 \pm 0.0007$ & $0.9646 \pm 0.0051$ & $0.9634 \pm 0.0136$ & $299.9 \pm 2.0$ & $11.72 \pm 0.14$ & $11.68 \pm 0.15$ \\
\hline CR007 U-Th-1 & $1.954 \pm 0.005$ & $0.1063 \pm 0.0015$ & $0.9615 \pm 0.0057$ & $0.9601 \pm 0.0230$ & $126.1 \pm 1.7$ & $12.79 \pm 0.25$ & $12.70 \pm 0.29$ \\
\hline CR008-A U-Th-1 & $1.903 \pm 0.002$ & $0.2871 \pm 0.0015$ & $0.9657 \pm 0.0042$ & $0.9617 \pm 0.0110$ & $1114.2 \pm 4.7$ & $38.57 \pm 0.40$ & $38.54 \pm 0.41$ \\
\hline CR008-B U-Th-1 & $9.023 \pm 0.008$ & $0.3535 \pm 0.0011$ & $0.9561 \pm 0.0031$ & $0.9494 \pm 0.0071$ & $8660.3 \pm 23.0$ & $50.54 \pm 0.35$ & $50.53 \pm 0.35$ \\
\hline CR020 U-Th-1 & $5.200 \pm 0.009$ & $0.2852 \pm 0.0008$ & $1.0233 \pm 0.0026$ & $1.0258 \pm 0.0064$ & $1038.1 \pm 2.6$ & $35.57 \pm 0.18$ & $35.54 \pm 0.20$ \\
\hline CR021 U-Th-2 & $2.946 \pm 0.005$ & $0.2951 \pm 0.0008$ & $1.0518 \pm 0.0026$ & $1.0573 \pm 0.0063$ & $1061.0 \pm 2.2$ & $35.81 \pm 0.17$ & $35.77 \pm 0.19$ \\
\hline CR023 U-Th-1 & $21.881 \pm 0.038$ & $0.5251 \pm 0.0014$ & $0.9718 \pm 0.0025$ & $0.9641 \pm 0.0068$ & $4910.6 \pm 9.8$ & $85.17 \pm 0.59$ & $85.15 \pm 0.60$ \\
\hline CR026 U-Th-2 & $3.215 \pm 0.004$ & $0.3362 \pm 0.0006$ & $0.9553 \pm 0.0024$ & $0.9489 \pm 0.0053$ & $632.8 \pm 1.6$ & $47.48 \pm 0.19$ & $47.41 \pm 0.24$ \\
\hline CR028 U-Th-1 & $7.033 \pm 0.009$ & $0.3974 \pm 0.0010$ & $0.9592 \pm 0.0023$ & $0.9519 \pm 0.0074$ & $313.9 \pm 0.7$ & $58.60 \pm 0.31$ & $58.40 \pm 0.43$ \\
\hline
\end{tabular}




\begin{tabular}{|c|c|c|c|c|c|c|c|}
\hline Sample name & ${ }^{238} \mathrm{U}$ (ppm) & $\left({ }^{230} \mathrm{Th} /{ }^{238} \mathrm{U}\right)_{\mathrm{m}}$ & $\left({ }^{234} \mathrm{U}{ }^{238} \mathrm{U}\right)_{\mathrm{m}}$ & $\left(\left.{ }^{234} U\right|^{238} U\right)_{\text {inital }}$ & $\left({ }^{230} \mathrm{Th} /{ }^{232} \mathrm{Th}\right)$ & Age uncorrected (ka) & Age detrital corrected \\
\hline CR029 U-Th-1 & $16.931 \pm 0.024$ & $0.4730 \pm 0.0012$ & $0.9764 \pm 0.0023$ & $0.9710 \pm 0.0061$ & $2833.1 \pm 5.6$ & $72.48 \pm 0.42$ & $72.45 \pm 0.44$ \\
\hline CR032 U-Th-1 & $5.287 \pm 0.006$ & $0.4538 \pm 0.0007$ & $0.9394 \pm 0.0023$ & $0.9256 \pm 0.0044$ & $5831.2 \pm 11.6$ & $72.60 \pm 0.32$ & $72.58 \pm 0.33$ \\
\hline CR032 U-Th-3 & $20.630 \pm 0.029$ & $0.4243 \pm 0.0007$ & $0.9430 \pm 0.0025$ & $0.9314 \pm 0.0050$ & $8525.6 \pm 17.3$ & $65.66 \pm 0.32$ & $65.65 \pm 0.33$ \\
\hline CR032 U-Th-4 & $16.053 \pm 0.023$ & $0.4100 \pm 0.0011$ & $0.9621 \pm 0.0027$ & $0.9550 \pm 0.0062$ & $12489.2 \pm 27.1$ & $60.83 \pm 0.37$ & $60.83 \pm 0.37$ \\
\hline CR032 U-Th-5 & $16.963 \pm 0.026$ & $0.4001 \pm 0.0013$ & $0.9566 \pm 0.0024$ & $0.9487 \pm 0.0065$ & $41603.3 \pm 204.9$ & $59.35 \pm 0.38$ & $59.35 \pm 0.38$ \\
\hline CR032 U-Th-6 & $9.081 \pm 0.014$ & $0.3443 \pm 0.0009$ & $0.9706 \pm 0.0024$ & $0.9663 \pm 0.0054$ & $13291.9 \pm 33.2$ & $47.90 \pm 0.24$ & $47.90 \pm 0.24$ \\
\hline CR033-B U-Th-3 & $9.766 \pm 0.014$ & $0.4103 \pm 0.0007$ & $0.9894 \pm 0.0024$ & $0.9874 \pm 0.0047$ & $3236.7 \pm 6.8$ & $58.48 \pm 0.24$ & $58.46 \pm 0.25$ \\
\hline CR034 U-Th-1 & $5.476 \pm 0.008$ & $0.2778 \pm 0.0005$ & $0.9995 \pm 0.0024$ & $0.9995 \pm 0.0044$ & $10480.6 \pm 29.5$ & $35.52 \pm 0.13$ & $35.51 \pm 0.13$ \\
\hline CR035-A U-Th-1 & $10.049 \pm 0.012$ & $0.5012 \pm 0.0010$ & $0.9379 \pm 0.0022$ & $0.9212 \pm 0.0051$ & $67400.3 \pm 200.5$ & $84.30 \pm 0.47$ & $84.30 \pm 0.47$ \\
\hline CR035-A U-Th-2 & $5.835 \pm 0.009$ & $0.4694 \pm 0.0012$ & $0.9423 \pm 0.0023$ & $0.9286 \pm 0.0061$ & $9564.4 \pm 26.4$ & $75.84 \pm 0.48$ & $75.83 \pm 0.49$ \\
\hline CR035-A U-Th-3 & $4.950 \pm 0.008$ & $0.4733 \pm 0.0017$ & $0.9402 \pm 0.0023$ & $0.9256 \pm 0.0074$ & $16165.7 \pm 51.4$ & $77.06 \pm 0.60$ & $77.05 \pm 0.61$ \\
\hline
\end{tabular}

Table 1: U-series data for the investigated Crag cave speleothem samples. All uncertainties are $2 \sigma$ errors. Ages are given in ka before present, where the reference is the year $2000 \mathrm{AD}$ (b2k). Decay constants of 9.17055436E-6 for ${ }^{230} \mathrm{Th}, 2.8220307 \mathrm{E}-6$ for ${ }^{234} \mathrm{U}$ after Cheng et al. (2013) and 1.55125E-10 for ${ }^{238} \mathrm{U}$ from Jaffey et al. (1971) were used. A correction for detrital thorium was applied using an activity ratio of $0.8 \pm 0.4$ as discussed by Richards and Dorale (2003). Corrected ages were used throughout.

\begin{tabular}{|c|c|c|c|c|c|}
\hline Dated event & Crag cave sample & $\begin{array}{l}\text { Estimated onset in } \\
\text { Crag cave (kyr b2K) }\end{array}$ & $\begin{array}{c}\text { INTIMATE/GICC05 } \\
\text { (Rasmussen et al., 2014) }\end{array}$ & $\begin{array}{l}\text { Buizert et al., } 2015 \\
=\text { GICC05 x } 1.0063\end{array}$ & $\begin{array}{l}\text { Hulu age after Buizert } \\
\text { et al. 2015) (kyr b2K) }\end{array}$ \\
\hline Start of Holocene & CR006 U-Th-1 & $11.68 \pm 0.15$ & $11.7 \pm 0.1$ & $11.78 \pm 0.1$ & \\
\hline $\mathrm{Gl}-2.2$ & CR025 U-Th-5 & $23.45 \pm 0.17$ & $23.34 \pm 0.6$ & $23.49 \pm 0.6$ & \\
\hline $\mathrm{GI}-3$ & CR025 U-Th-4 & $27.92 \pm 0.16$ & $27.78 \pm 0.83$ & $27.96 \pm 0.83$ & $27.972 \pm 0.095$ \\
\hline GI-4 & CR025 U-Th-18 & $29.61 \pm 0.12$ & $28.9 \pm 0.9$ & $29.08 \pm 0.9$ & $29.184 \pm 0.092$ \\
\hline GI-5.1 & C58-2 U-Th-17 & $30.92 \pm 0.13$ & $30.84 \pm 1.02$ & $31.03 \pm 1.02$ & $30.926 \pm 0.255$ \\
\hline $\mathrm{GI}-5.2^{*}$ & & $32.56 \pm 0.26$ & $32.5 \pm 1.13$ & $32.7 \pm 1.13$ & $32.717 \pm 0.236$ \\
\hline GI-6 & C58-2 U-Th-15 & $33.94 \pm 0.16$ & $33.74 \pm 1.21$ & $33.95 \pm 1.21$ & $34.084 \pm 0.337$ \\
\hline GI-8c & CR025 U-Th-15 & $38.65 \pm 0.19$ & $38.22 \pm 1.45$ & $38.46 \pm 1.45$ & $38.357 \pm 0.155$ \\
\hline GI-9 & CR025 U-Th-26 & $40.59 \pm 0.18$ & $40.16 \pm 1.58$ & $40.41 \pm 1.58$ & $40.314 \pm 0.241$ \\
\hline GI-10 & C58-2 U-Th-8 & $41.9 \pm 0.17$ & $41.46 \pm 1.63$ & $41.72 \pm 1.63$ & $41.714 \pm 0.31$ \\
\hline GI-11 & CR025 U-Th-3 & $43.94 \pm 0.28$ & $43.34 \pm 1.74$ & $43.61 \pm 1.74$ & $43.684 \pm 0.144$ \\
\hline $\mathrm{Gl}-13 \mathrm{c}$ & CR008-B U-Th-1 & $50.53 \pm 0.35$ & $49.28 \pm 2.03$ & $49.59 \pm 2.03$ & $49.612 \pm 0.251$ \\
\hline GI-16.2 & CR028 U-Th-1 & $58.4 \pm 0.43$ & $58.28 \pm 2.51$ & $58.65 \pm 2.51$ & \\
\hline GI-19.2 & CR005 U-Th-5 & $73.09 \pm 0.67$ & $72.34 \pm$ unknown & $72.8 \pm$ unknown & \\
\hline $\mathrm{GI}-20 \mathrm{c}$ & CR035-A U-Th-3 & $77.05 \pm 0.61$ & $76.44 \pm$ unknown & $76.92 \pm$ unknown & \\
\hline $\mathrm{GI}-21.1 \mathrm{c}$ & CR005 U-Th-7 & $79.43 \pm 0.47$ & $79.24 \pm$ unknown & $79.74 \pm$ unknown & \\
\hline GI-21.2 & CR023 U-Th-1 & $85.15 \pm 0.6$ & $85.06 \pm$ unknown & $85.6 \pm$ unknown & \\
\hline
\end{tabular}

Table 2: Proposed correlations between the onset of speleothem deposition at Crag cave during the last glacial and the Greenland Interstadial event stratigraphy after Rasmussen et al. (2014). Uncertainties are given as $2 \sigma$. 


\section{Supplementary Figure Captions}

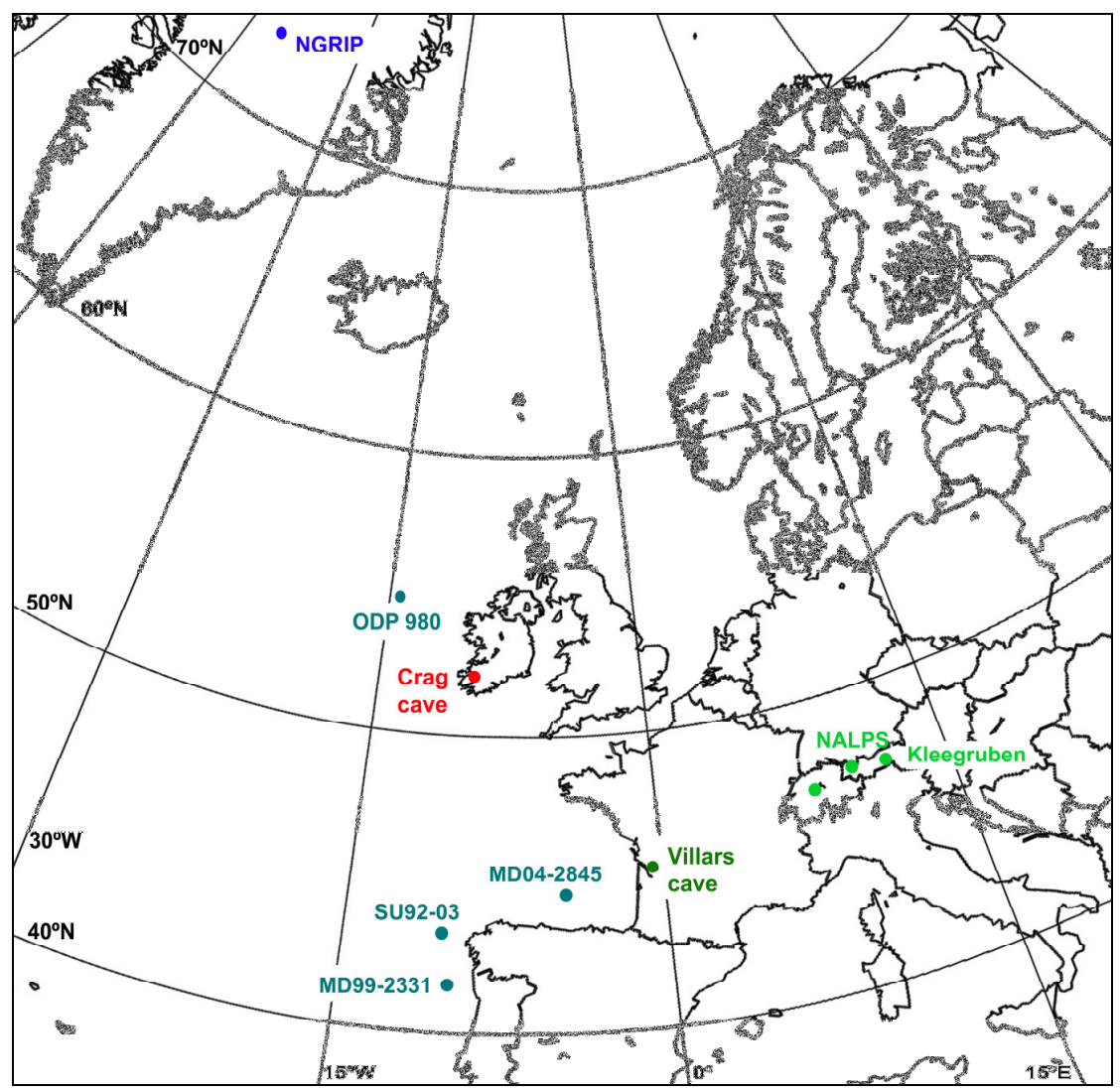

Fig. S1: Map showing the position of Crag cave (red), the Greenland ice core NGRIP (North Greenland Ice Core Project Members, 2004), marine sediment cores ODP980 (McManus et al., 2001), and MD99-2331 (Sánchez Goñi et al., 2008), SU92-03 (Salgueiro et al., 2010), MD99-2845 (Sánchez Goñi et al., 2008), Villars cave (Genty et al., 2003, 2010; Wainer et al., 2009) and Alpine cave sites (Spötl et al., 2006; Boch et al., 2011; Moseley et al., 2014). 


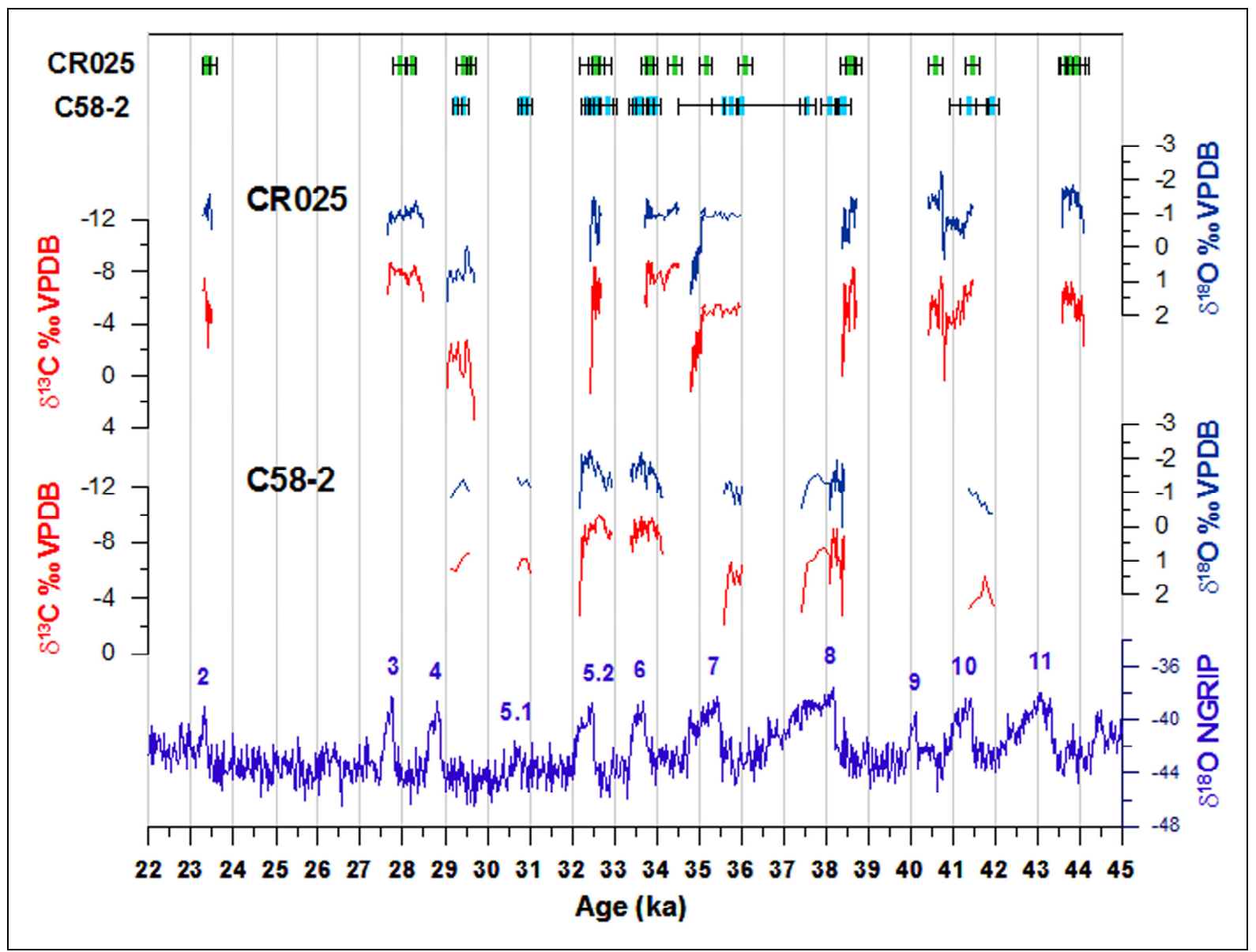

Fig. S2: $\delta^{18} \mathrm{O}$ (blue) and $\delta^{13} \mathrm{C}$ (red) values for stalagmite CR025 and C58-2 and NGRIP $\delta^{18} \mathrm{O}$ to correlate the depositional intervals to GI. The age model of the stable isotope records for the individual depositional phases are made by interpolation and extrapolation, with the relevant available U-Th ages. This is a simplification and may mask depositional rate changes due to the limited number of U-Th ages. $\delta^{13} \mathrm{C}$ values more than $-4.0 \%$ are attributed to kinetic isotope fractionation. 


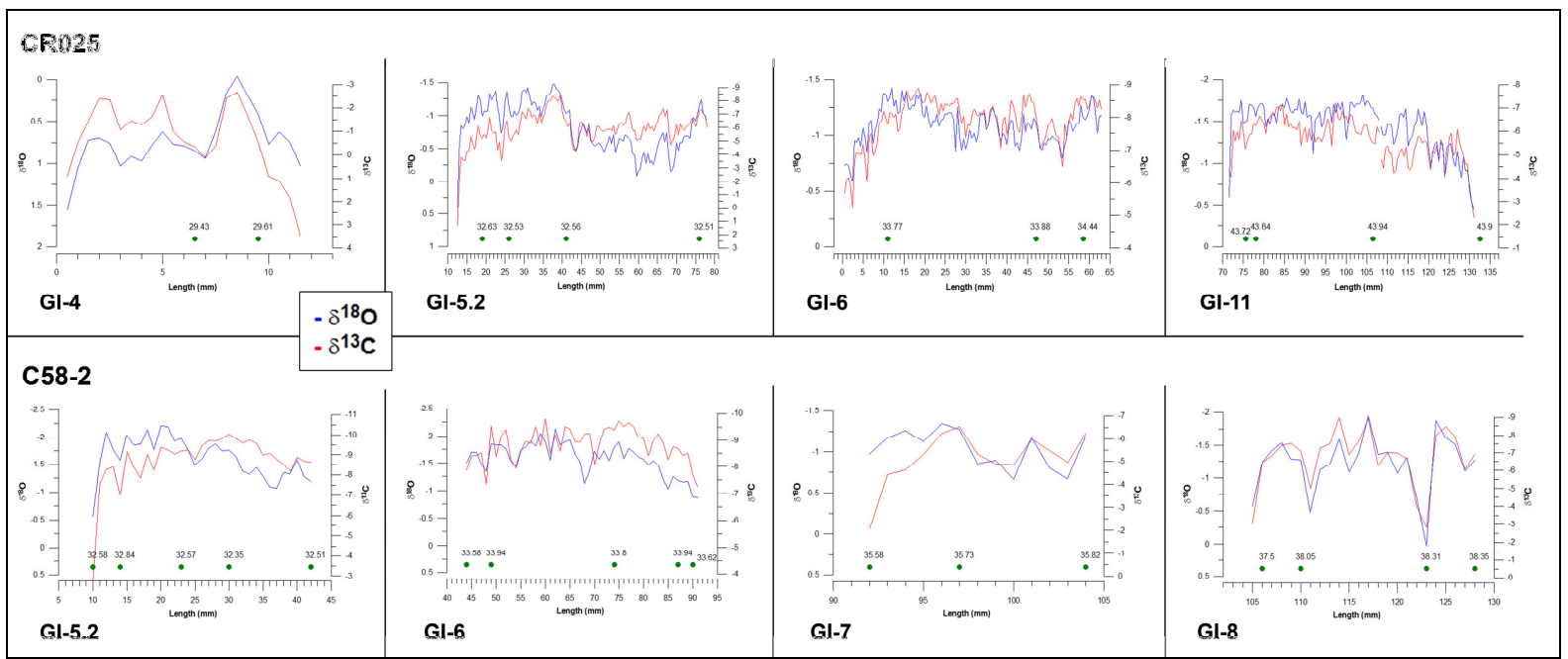

Fig S3: $\delta^{18} \mathrm{O}$ (blue) and $\delta^{13} \mathrm{C}$ (red) values for selected sections of stalagmite CR025 and C582 , showing changes in isotope values as a function of distance into and out of the selected GI events. Green dots show the location and values of U-series ages. In many cases the isotope shifts occurred more rapidly than could be resolved by the U-series dating. In several cases (e.g. GI-5.2 and GI-6 in sample CR025, GI-5.2, GI-6, GI-8 in sample C58-2) immediately following the onset of calcite growth (right hand side of each panel).

Shifts to higher values at the end of depositional intervals also occurred rapidly on decadal to centennial timescales (left hand side of panels on Fig. S3), interpreted to reflect the onset of kinetic isotope fractionation processes as a result of cold/dry conditions before the cessation of speleothem depositional phases. 